\title{
Anti-Inflammatory and Immunomodulatory Properties of Fermented Plant Foods
}

\author{
Roghayeh Shahbazi ${ }^{1}$, Farzaneh Sharifzad ${ }^{1}$, Rana Bagheri ${ }^{2}$, Nawal Alsadi ${ }^{1}$, Hamed Yasavoli-Sharahi ${ }^{1}$ \\ and Chantal Matar 1,3,*
}

1 Cellular and Molecular Medicine Department, Faculty of Medicine, University of Ottawa, Ottawa, ON K1H 8M5, Canada; rshah017@uottawa.ca (R.S.); fsharifz@uottawa.ca (F.S.); nalsa068@uottawa.ca (N.A.); hyasa068@uottawa.ca (H.Y.-S.)

2 College of Liberal Art and Sciences, Portland State University, Portland, OR 97201, USA; rbagheri@pdx.edu

3 School of Nutrition, Faculty of Health Sciences, University of Ottawa, Ottawa, ON K1H 8M5, Canada

* Correspondence: Chantal.matar@uottawa.ca; Tel.: +1-613-562-5406

Citation: Shahbazi, R.; Sharifzad, F.; Bagheri, R.; Alsadi, N.; Yasavoli-Sharahi, H.; Matar, C. Anti-Inflammatory and Immunomodulatory Properties of Fermented Plant Foods. Nutrients 2021, 13, 1516. https://doi.org/ $10.3390 /$ nu13051516

Academic Editor: Stan Kubow

Received: 8 April 2021

Accepted: 29 April 2021

Published: 30 April 2021

Publisher's Note: MDPI stays neutral with regard to jurisdictional claims in published maps and institutional affiliations.

Copyright: (c) 2021 by the authors. Licensee MDPI, Basel, Switzerland. This article is an open access article distributed under the terms and conditions of the Creative Commons Attribution (CC BY) license (https:/ / creativecommons.org/licenses/by/ $4.0 /)$.
Abstract: Fermented plant foods are gaining wide interest worldwide as healthy foods due to their unique sensory features and their health-promoting potentials, such as antiobesity, antidiabetic, antihypertensive, and anticarcinogenic activities. Many fermented foods are a rich source of nutrients, phytochemicals, bioactive compounds, and probiotic microbes. The excellent biological activities of these functional foods, such as anti-inflammatory and immunomodulatory functions, are widely attributable to their high antioxidant content and lactic acid-producing bacteria (LAB). LAB contribute to the maintenance of a healthy gut microbiota composition and improvement of local and systemic immunity. Besides, antioxidant compounds are involved in several functional properties of fermented plant products by neutralizing free radicals, regulating antioxidant enzyme activities, reducing oxidative stress, ameliorating inflammatory responses, and enhancing immune system performance. Therefore, these products may protect against chronic inflammatory diseases, which are known as the leading cause of mortality worldwide. Given that a large body of evidence supports the role of fermented plant foods in health promotion and disease prevention, we aim to discuss the potential anti-inflammatory and immunomodulatory properties of selected fermented plant foods, including berries, cabbage, and soybean products, and their effects on gut microbiota.

Keywords: fermented plant foods; fermented blueberries; fermented blackberries; sauerkraut; kimchi; soybean; immunomodulation; inflammation; gut microbiota

\section{Introduction}

Chronic inflammatory diseases are the leading cause of mortality worldwide [1,2]. Inflammation is part of the host's complex defense mechanism. It is the immune system's biological response against different infectious or non-infectious stimuli [1,3-5]. These stimuli may activate inflammatory signaling pathways such as nuclear factor-kappa B (NF-kB), mitogen-activated protein kinase (MAPK), and Janus kinase-signal transducer and activator of transcription (JAK-STAT) pathways underlying the pathology of many chronic diseases [1,4]. Exploring the potential role of natural bioactive components in preventing and treating chronic inflammatory disorders such as cancers, obesity, diabetes, rheumatoid arthritis, atherosclerosis, ischemic heart disease, and inflammatory bowel disease (IBD) is now the subject of intense research [6].

Historically, natural products have been known to exert significant biological and pharmacological properties and play a valuable role in drug discovery and treating many diseases [6-9]. Due to significant anti-infective, antioxidative, anti-inflammatory, antiangiogenic, and anticarcinogenic properties [9], many natural compounds have been applied as preventive and therapeutic agents against many ailments $[9,10]$. Fermented plant products 
are highly popular foods worldwide, and are a rich source of natural compounds such as probiotics and phytochemicals with known biological properties [11-16].

Traditionally, fermentation was a method to preserve foods for a longer time; however, this process recently has attracted great attention due to the increase in the nutritional value of foods and the production of health-promoting components [17-20]. Over fermentation, the microorganisms responsible for this process generate bioactive compounds by metabolizing fermentable carbohydrates and proteins $[17,20,21]$. Generated metabolic compounds play a significant protective role against chronic disorders, including obesity, diabetes, cancer, cardiovascular disease, and allergies $[17,21]$. Moreover, fermentation increases the peptides, amino acids, vitamins, minerals, and antioxidant contents of foods [20,22].

Nowadays, a wide range of fermented products is produced and consumed worldwide $[22,23]$. Although dairy products remain the main source of probiotic bacteria in our diet, fermented plant foods are unique sources of health-promoting probiotics such as lactic acid-producing bacteria (LAB) [18]. Lactobacillus, Leuconostoc, Pediococcus, and Weissella genera are the main LAB involved in plant foods' fermentation process [18,20,24-27]. Although the fermentation process is ensured by probiotic microorganisms, including LAB and probiotic yeast such as $S$. boulardii, these microorganisms may be destroyed during the heating process yielding fermented products with no live microbes. However, even in these cases, the fermentation process before pasteurization will enrich the fermented foods with small compounds released from existing phytonutrients or by releasing active metabolites from the fermentation process itself $[28,29]$.

The gut remains the most important organ in which fermented foods exert their beneficial effects, either by systemically modulating the immune response or positively influencing the gut microbiota. $[28,29]$. The human gut microbiota consists of diverse microorganisms, including archaea, bacteria, viruses, and yeasts, which maintain a symbiotic relationship with the host [30-33]. There is a mutual influence between gut microbiota and the immune system. Gut microbiota play a key role in the function and homeostasis of the immune system by the maturation of gut-associated lymphoid tissue and innate lymphoid cells, enhancing antimicrobial peptides, antibodies, and cytokines production, inducing immunoglobulin A (IgA)-producing B cells and $\mathrm{T}$ cells differentiation, and regulating $\mathrm{T}$ helper 17 (Th17)/regulatory T cells (Tregs) balance [34-39]. Gut microbiota perturbation negatively affects the immune system and leads to inflammation [4].

The anti-inflammatory and immunomodulatory properties of plant-based fermented foods are well documented [40-42]. The functional properties of fermented products are, in part, related to the probiotics content of the products [29]. Numerous health-promoting benefits have been attributed to probiotics due to their anti-inflammatory and immunomodulatory activities at the gut level and beyond [4,43-46]. Probiotic consumption in the form of fermented foods can improve gut barrier integrity and gut immunity and maintain gut homeostasis $[4,29,47]$, through different mechanisms, including the inhibition of pathogen colonization, the induction of antimicrobial peptides production and mucus secretion, the increase of $\operatorname{IgA}$ production, the down-regulation of the Th17 and pro-inflammatory cytokines such as IL-17F, IL-23, and the upregulation of Tregs production [48-51].

Moreover, fermentation will lead to the degradation of complex phytochemical molecules into smaller bioactive polyphenols. Studies have shown that polyphenolic compounds found in fermented products are beneficial in microbiota metabolism and growth [52] and can inhibit the production of inflammatory cytokines and suppress inflammatory responses [53]. Furthermore, neutralizing free radicals, regulating antioxidant enzyme activities, reducing oxidative stress, and enhancing immune system activity are other potential mechanisms by which plant-based fermented foods and beverages exert health benefits $[54,55]$.

Different plants, such as fruits, vegetables, tea, grains, legumes, and starchy roots, are used to produce plant-based fermented foods [20,22,23,29,53]. Given the growing evidence suggesting the precious role of fermented plant products in health promotion or disease prevention [56,57], in this review, we will discuss the potential anti-inflammatory 
and immunomodulatory properties of selected fermented plant foods, including berries, cabbage and soy products, and their effects on gut microbiota.

\section{Fermented Berries}

Berry fruits are well known for their significant health benefits [58,59]. Various berries have been shown to have anti-inflammatory and immunomodulatory activities $[60,61]$, reduce the risk of cardiovascular diseases [58], neurodegenerative disease [62], diabetes mellitus [63], and protect against cancer [64]. Berries are a good source of various micronutrients and bioactive compounds with antioxidant properties, including vitamins $C$ and $\mathrm{E}$, selenium, carotenoids, and most importantly, phytochemicals such as anthocyanin and tannins $[58,59,61,65]$. The bioavailability of berry polyphenols is low $[58,65]$, therefore, it has been suggested that the functional properties of the polyphenolic components of berries are related to their metabolites produced over colonic fermentation by gut microorganism $[61,65]$. Interestingly, berry polyphenols and their metabolites affect gut microbial composition by increasing the frequency of beneficial genera, including Bifidobacterium, Lactobacillus, and Akkermansia [61]. Moreover, berry metabolites have been shown to suppress inflammatory cytokines and mitigate gut inflammation [61].

Fermentation may increase the positive effects of berries due to an increase in polyphenols and the antioxidant capacity of fermented products [66]. Figure 1 illustrates the anti-inflammatory and immunomodulatory activity of fermented berries.

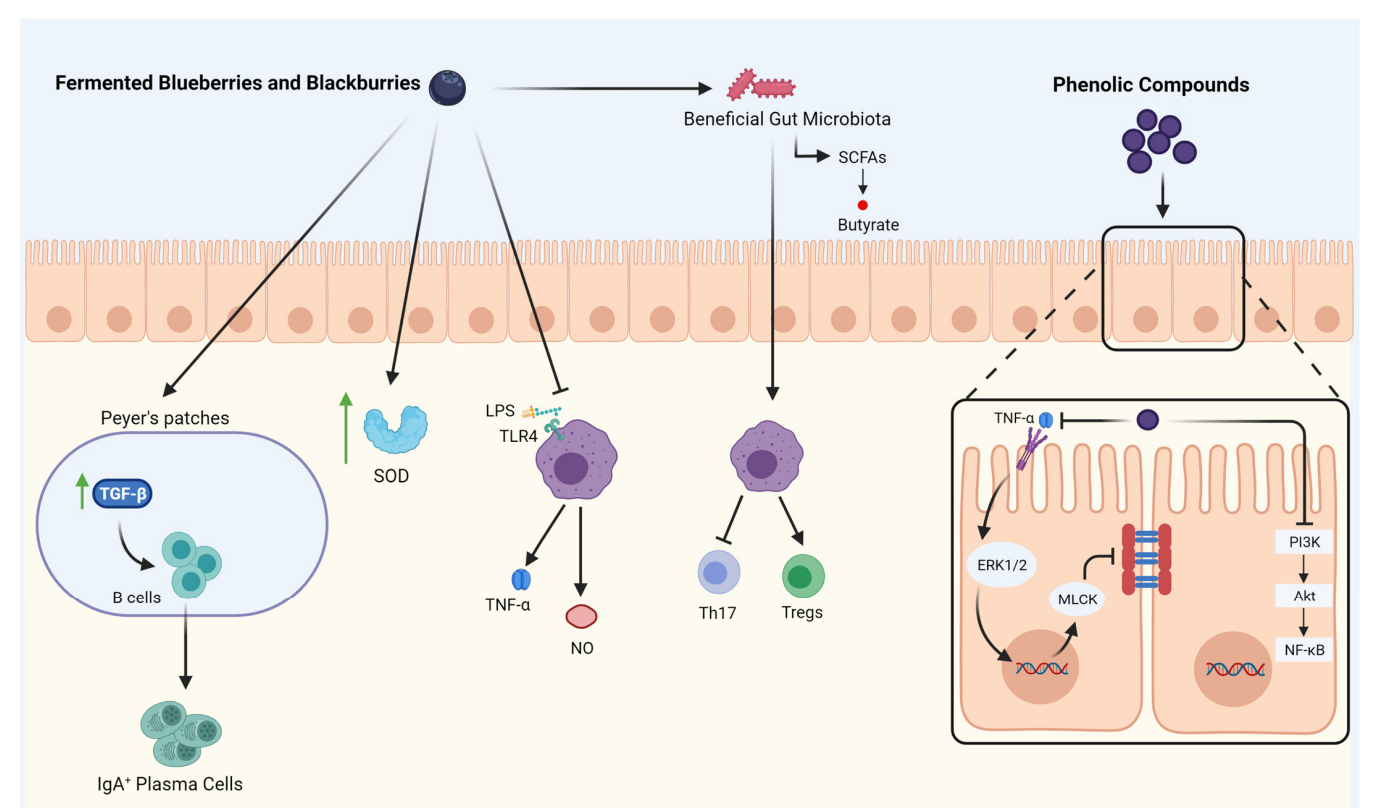

Figure 1. The Anti-inflammatory and Immunomodulatory activity of fermented berries. $\uparrow:$ increase; TGF- $\beta$ : transforming growth factor-beta; IgA: immunoglobulin A; SOD: su-peroxide dismutase; LPS: Lipopolysaccharide; TLR4: Toll-like receptor-4; TNF- $\alpha$ : tumor necrosis factor; NO: nitric oxide; SCFAs: short-chain fatty acids; Th17: T helper 17; Tregs: regulatory T cells; PI3K: phosphatidylinositol 3 kinase; AKT: protein kinase B; NF-kB: nu-clear factor-kappa B; MLCK: myosin light-chain kinase; ERK: signal-regulated kinase.

Fermented blueberries and blackberries modulate the gut microbiota populations by increasing beneficial bacteria. Moreover, they improve the production of short-chain fatty acids (SCFAs) and enhance mucosal immunity by promoting secretory $\operatorname{IgA}(\operatorname{sg} \mathrm{A})$ cells through increasing TGF- $\beta$ activity. Fermented blueberries and blackberries also induce antioxidant enzymes like superoxidase dismutase (SOD), which increase the radical scavenging capacity. Furthermore, the inflammatory responses are inhibited by inhibiting macrophage pro-inflammatory mediators release (nitric oxide, TNF- $\alpha$ ). It also influences 
immune cells by inhibiting Th17 activity and the differentiation of Tregs. The phenolic compounds released by the digestion of blackberries and blueberries inhibit PI3K/Akt/NF- $\mathrm{B}$ signaling pathway and improve the gut barrier. Moreover, phenolic compounds decrease gut permeability by inhibiting TNF- $\alpha$ and its downstream, including ERK1/2 and MLCK. Created with Biorender.com (accessed on 29 April 2021).

\subsection{Fermented Blueberries}

Blueberries are among the richest sources of phenolic compounds, such as anthocyanins, flavonols, and proanthocyanidins which possess high antioxidant capacity $[67,68]$. Because of the high content of phenolic compounds, blueberries are known to have valuable health effects $[67,69-71]$. Biotransformation of blueberries during the fermentation process increases their phenolic compounds content and bioavailability, as well as antioxidant activity [72,73]. Numerous in vitro and animal studies have shown significant anti-inflammatory properties of fermented blueberries through counteracting reactive oxygen species (ROS), suppressing the expression of pro-inflammatory cytokines, and inhibiting inflammatory signaling pathways [72] and, therefore, exerting a protective function against chronic inflammatory disorders such as obesity [74], diabetes [63,74], neurodegenerative diseases [75], and cancer [72].

Lipopolysaccharide (LPS) is the main outer layer component of Gram-negative bacteria which can stimulate the innate immune system and inflammation by activation of the Toll-like receptor-4 (TLR4)/NF-kB signaling pathway [76]. LPS-stimulated macrophages are one of the best models for studying the anti-inflammatory potential of different phytochemicals in foods [77]. Macrophages are the most important immune cells that contribute to the initiation of inflammation by secreting pro-inflammatory mediators and cytokines such as nitric oxide (NO) and tumor necrosis factor (TNF- $\alpha$ ) [78]. Overproduction of NO by inducible NO synthase (iNOS) contributes to developing inflammatory conditions $[62,79,80]$. Fermented blueberry and cranberry juices (fermented with bacterium Serratia vaccinii, isolated from blueberry microflora) have been reported to suppress NO production activated by LPS/interferon-gamma (INF- $\gamma$ ) in mouse macrophage [62]. Also, fermented polyphenol-enriched blueberry preparation (PEBP) could inhibit breast cancer cell line growth and breast cancer stem cells development. In vivo, PEBP inhibited tumor development, the formation of ex vivo mammospheres, and lung metastasis. PEBP exerted its anticarcinogenic effects through regulating the activity of transcription factors as well as phosphatidylinositol 3-kinase (PI3K)/protein kinase B (AKT), MAPK/extracellular signal-regulated kinase (ERK), and STAT3 pathways [72].

Fermented blueberries may counteract obesity and diabetes, at least partly, through anti-inflammatory and antioxidant activities [74]. The administration of fermented blueberry juice reduced hyperglycemia in diabetic mice and inhibited the development of obesity, glucose intolerance, and diabetes in pre-diabetic KKAy mice. Fermented blueberry juice displayed its antiobesity and antidiabetic role by mitigating oxidative stress and increasing adiponectin levels [74]. Adiponectin decreases tissue triglyceride content and insulin resistance [81]. Adiponectin gene expression is inhibited by ROS [74] and pro-inflammatory cytokines [74,82].

Fermented blueberries may prevent neurodegenerative disease through antiinflammatory and antioxidant activity [75]. ROS-induced oxidative stress causes neuronal cell damage. In neuronal cell culture, fermented blueberries with Serratia vaccinii induced antioxidant enzymes activities and prevented neuronal cell death through the upregulation of cell survival signaling pathways such as MAPK family enzymes p38 and c-Jun Nterminal kinase (JNK) and the downregulation of cell death pathways such as ERK1/2 and MAPK/ERK kinase (MEK1/2) [75]. Furthermore, the antioxidant and antiproliferative activity of fermented blueberries with Lactobacillus plantarum (L. plantarum) has been found in human cervical carcinoma HeLa cells [83].

Evidence has shown the health benefits of fermented blueberries may be to some extent attributable to gut microbiota modulation $[84,85]$. In an in vitro model, fermentation 
of blueberry pomace with Lactobacillus casei (L. casei) increased its antioxidant activity by a significant increase in superoxide dismutase activity and radical scavenging capacity. Fermented blueberry pomace also improved gut function by altering fecal microbial composition through inhibiting Escherichia coli, Enterococcus, and increasing the abundance of beneficial microbiota such as Bifidobacterium, Ruminococcus, Lactobacillus, Akkermansia genera, and butyrate-producing bacteria, and increasing the short-chain fatty acid (SCFAs) production [84]. In the in vivo model, the effect of supplementation of mice receiving a high-fat diet with L. casei-fermented blueberry pomace was assayed on gut immunity and microbiota [85]. Fermented blueberry supplementation improved mucosal immunity by promoting secretory $\operatorname{IgA}(\mathrm{sIg} A)$ secretion and transforming growth factor-beta (TGF- $\beta$ ) levels in the intestine. TGF- $\beta$ is an intestinal mucosal immunity modulator and a key mediator in stimulating the IgA+ B cells production in Peyer's patches of the intestine. A high-fat diet is associated with a decrease in TGF- $\beta$ level $[85,86]$. Besides, fermented blueberries altered the gut microbiota's composition and frequency toward an increase in Bifidobacterium, Lactobacillus, and Akkermansia bacteria and a decrease in Firmicutes phyla [85]. Fermented blueberries also increased the production of SCFAs. Therefore, fermented blueberries increased sIgA level by improving gut microbiota and SCFAs production [85]. Moreover, this product has been shown to counteract intestinal inflammation by the reduction of TNF- $\alpha$ and myeloperoxidase and inducing interleukin (IL-10) production and improved gut barrier function and immunity by regulating NF- $\mathrm{kB} /$ myosin light-chain kinase (MLCK) signaling [87] and the overexpression of MLCK results in gut barrier permeability and dysfunction $[87,88]$.

The antihypertensive activity of fermented blueberries through gut microbiota modulation has been studied in rats $[89,90]$. In a study in rats, intake of freeze-dried fermented blueberries with L. plantarum DSM 15,313 significantly decreased blood pressure in healthy rats and rats with L-NAME induced hypertension, while a change in gut cecal microbiome was observed in healthy rats [89]. In a similar study, no significant effects were observed on blood pressure and cecal microbial community diversity following feeding hypertensive rats with L. plantarum fermented blueberries [90].

Zhong et al. (2020) investigated the effect of blueberry products on metabolic syndrome by regulating the gut microbial population [91]. They supplemented high-fat-fed mice with fresh blueberry juice or fermented blueberry juice. Both juices could reduce fat accumulation, hyperlipidemia, and insulin resistance in mice. A high level of SCFAs production was observed in both groups; SCFAs may reduce insulin resistance by suppressing pro-inflammatory cytokine production [91]. Furthermore, fresh and fermented juices enhanced the diversity and richness of the gut microbial population. Interestingly, the fermented blueberry group demonstrated a low frequency of some obesity-related genera such as Oscillibacter and Alistipes belonging to the Firmicutes phyla and a high frequency of leanness-related genera such as Akkermansia, Barnesiella, Olsenella, Bifidobacterium, and Lactobacillus. Therefore, blueberry products could reduce metabolic syndrome symptoms, partly by modulating gut microbiota [91]. In a study in a polygenic mouse model of obesity, supplementation with blueberry changed gut microbiota composition towards a substantial rise in the population of Bacteroidetes and Actinobacteria and improved the obesity-related metabolic outcomes [92].

\subsection{Fermented Blackberries}

Blackberry is known for its high content of antioxidant compounds, particularly anthocyanins, ellagitannins, gallic acid, and significant antioxidant capacity based on its high oxygen radical absorbance capacity [93,94]. Preclinical and clinical studies have shown a protective effect of this fruit against chronic diseases by inhibiting oxidative stress and inflammation [93]. As aforementioned, the fermentation process leads to an increase in the berries' phenolic content $[67,95,96]$, so fermented blackberry juice may exert more health benefits compared to non-fermented juice [97]. 
Some studies have shown the anti-inflammatory potential of anthocyanins and proanthocyanidins from fermented blueberry-blackberry beverages through NF- $\mathrm{kB}$ signaling inhibition [66]. Adipose tissue hyperplasia during obesity induces the secretion of adipocytokines such as leptin, interleukin-6 (IL-6), interleukin-1 $\beta$ (IL-1 $\beta$ ), IL-10, TNF- $\alpha$, monocyte chemo-attractant protein-1, and plasminogen activator inhibitor-1, which are responsible for obesity-related inflammation [98]. Some of the released adipokines induce the infiltration of inflammatory macrophages into the adipose tissue and exacerbate the inflammatory responses [99]. An in vitro adipose tissue inflammatory model revealed the potential role of enriched anthocyanin fractions from blueberry-blackberry fermented beverages in the inhibition of inflammatory responses related to obesity through reducing the secretion of NO, TNF- $\alpha$, and inhibition of NF-KB activation in LPS-induced mouse macrophage. Those fractions also reduced intracellular fat accumulation in adipocytes and increased insulin-induced glucose uptake in adipocytes [100].

Oxidative stress contributes to the photoaging process. The high expression of iNOS and cyclooxygenase 2 (COX-2) in photoaged skin has been reported [101,102]. UVB induces ROS production, and ROS induces the expression of iNOS and COX-2, leading to inflammatory responses and skin damage [103]. Besides, UVB activates the NF-kB pathway, which is a pivotal mediator of the immuno-inflammatory reactions occurring in the pathogenesis of different dermatologic disorders [104,105]. Kim et al. (2019) showed the protective effect of fermented blackberry against ultraviolet B (UVB)-induced skin photoaging. They found that fermentation of blackberry with L. plantarum increased the antioxidant capacity of the fruit, inhibited activation of NF- $\mathrm{KB}$ signaling, and reduced the production of iNOS and COX-2 [103].

Although we could not find published research investigating the fermented blackberry products' influence on the gut microbial composition, the beneficial impact of nonfermented blackberry and its compounds on gut microbiota and the mitigation of inflammatory conditions related to gut microbial dysbiosis has been investigated [106]. For example, blackberry anthocyanin-rich extract can restore high-fat diet-induced gut microbiota dysbiosis in Wistar rats. This extract can recover gut microbial diversity and protect against dysbiosis-induced neuroinflammation [106]. Further, a mixture of blackberry fruit and leaf extracts effectively prevented diet-induced non-alcoholic fatty liver disease in Sprague-Dawley rats [107]. Feeding rats with the mixture resulted in an elevation in antioxidant enzyme capacity, mitigation of inflammatory responses, modulation of gut microbiota by increasing the frequency of Lactobacillus and Akkermansia in the fecal samples, enhancement of the gut integrity, and increase in the frequency of mucus-secreting goblet cells [107].

\section{Fermented Cabbage Products}

Cabbage is a rich source of phenolic compounds and is well known due to its unique health benefits such as anti-inflammatory, antioxidant, and cancer-protective properties [108]. Studies have shown the positive impact of fermented cabbage products such as sauerkraut and kimchi on health [109].

\subsection{Sauerkraut}

Sauerkraut is a nutritious fermented cabbage product widely consumed as a traditional dish in many European and Asian nations and the United States $[110,111]$. It is produced by LAB fermentation of shredded, fresh white cabbage salted with $2-3 \%$ sodium chloride [110,111]; salt is added to provide an anaerobic environment and prevent microbiological spoilage [77]. Leuconostoc mesenteroides (L. mesenteroides), L. plantarum, Lactobacillus brevis, Pediococcus pentosaceus, and Enterococcus are the main bacterial species involved in the fermentation process of cabbage [112-114]. Sauerkraut is highly popular due to its sensory features, its nutritional value and its medicinal potentials [110,112]. Scientific research strongly supports the health-promoting properties of sauerkraut by exerting antiinflammatory, antioxidant, and anticarcinogenic activities and protecting against oxidative 
DNA damage $[77,115,116]$. Bioactive compounds derived from glucosinolate hydrolysis, such as indol-3-carbinol, ascorbigen, sulforaphane, and allyl isothiocyanate, account for the favorable health effects of sauerkraut [77]. This fermented food is an excellent source of antioxidant vitamins such as vitamins $E$ and $C$ [77]. In a study, sauerkraut has been shown to exert anti-inflammatory activity by reducing NO production in LPS-induced murine macrophages RAW 264.7 [117]. Allyl isothiocyanate and indol-3-carbinol might be, in part, responsible for the anti-inflammatory activity of sauerkraut through different mechanisms such as the inhibition of pro-inflammatory cytokines production (like TNF- $\alpha$, and IL-1 $\beta$ ), pro-inflammatory enzymes expression (like iNOS), NF- $\mathrm{kB}$ pathway activation, and the reduction of pro-inflammatory microRNA-155 level in induced macrophages [118].

Furthermore, sauerkraut is a unique source of LAB [119-121]. LAB are major species considered as probiotics that promote innate and adaptive immunity and attenuate inflammation through modulating gut microbiota $[122,123]$. For example, in a study, administration of $L A B$ strains to $B A L B / c$ mice attenuated allergen-induced airway inflammation by regulating Th1/Th2 balance and up-regulation of Tregs [123]. Microbiome analysis revealed that $\mathrm{LAB}$ administration increased the dominant phyla frequency in the gut microbiota (Firmicutes and Bacteroidetes), which display a significant role in immune system development and maintenance [123]. Sauerkraut derived-LAB modulate immune function and enhance antibacterial response by inducing bacteriocins and IgA secretion [124,125]. LAB strains extracted from fermented cabbage could display immunomodulatory and anti-inflammatory activity in ovalbumin-sensitized BALB/c mice by downregulation of TLR-4 expression and modulation of B-cells and T-cells responses [126]. Also, it has been ascertained that the addition of the culture of L. mesenteroides, the key bacteria in the initiation fermentation process of sauerkraut, to sauerkraut enhances the innate and adaptive immune response in Escherichia coli-infected BALB/c mice [124].

There are limited human studies concerning the health benefits of sauerkraut and its effect on human gut microbiota. In a clinical trial involving 8 patients with mesenteric angina, significant differences were observed in disease burden between the 2 groups receiving French cassoulet or international sauerkraut [127]. In another clinical trial, pasteurized or unpasteurized sauerkraut effects on gut microbiota composition were assayed in 34 patients with irritable bowel syndrome (IBS). Gastrointestinal symptom severity significantly decreased in both groups. Moreover, a significant change in gut microbiota was found in both groups. However, the frequency of sauerkraut-related LAB such as $L$. plantarum and L. brevis were significantly higher in fecal samples of the group consuming unpasteurized sauerkraut, indicating that prebiotic bacteria were partly responsible for favorable effects of sauerkraut in IBS [128]. D-phenyllactic acid, a phenolic compound produced by sauerkraut LAB, firmly attaches to the hydroxycarboxylic acid receptor 3 (HCA3). HCA3 is a member of $G$ protein-coupled receptors for hydroxycarboxylic acids, which play an essential role in regulating immune functions. In a study, ingestion of sauerkraut increased the level of D-phenyllactic in plasma and urine samples of participants and induced immune cell activation [129].

\subsection{Kimchi}

Kimchi is a naturally fermented vegetable food with LAB [130,131]. It is the traditional side dish in Korea which is made of different raw vegetables, mainly Chinese cabbage (Brassica rapa), fermented in a seasoning mixture such as red pepper, garlic, ginger, and green onion and fermented seafood sauce $[110,112,114,131-134]$. Kimchi is a functional food containing a high level of $\mathrm{LAB}$, nutrients, vitamins, and phytochemicals such as indole compounds, b-sitosterol, benzyl isothiocyanate, and thiocyanate [131,132,135], which plays various physiological roles in the human body, including antioxidative, anti-inflammatory, anticarcinogenic, antiaging, antiobesity, antidiabetic, antihypertensive, anti-constipation, and lipid-lowering activities [131,132,136-138]. Kimchi is considered a unique probiotic food which $10^{8-9}$ CFU/g LAB remaining alive in kimchi after the fermentation [136]. 
Different strains of Leuconostoc, Weissella, Lactobacillus, and Pediococcus are among the main genera contributing to the kimchi fermentation process $[110,132,139]$.

A large body of research has proven the positive health effects of kimchi $[130,137,140,141]$. Kimchi and its ingredients exert an anti-inflammatory function by suppressing COX-2 and iNOS expression and NF-KB pathway activation [142,143]. Antioxidant and antiinflammatory effects of this functional food are attributable, at least in part, to its biological compounds generated during fermentation [144]. In animal studies, the dichloromethane fractions of the kimchi have been reported to display high free radical scavenging capacity and a high antioxidant effect against LDL oxidation [130]. Also, KIMCHI3-(40-Hydroxyl30,50-dimethoxyphenyl) propionic acid, a bioactive compound from kimchi, could alleviate inflammation in LPS-stimulated BV2 microglial cells by attenuating LPS-induced proinflammatory cytokines secretion such as TNF- $\alpha$ and IL- $1 \beta$, through inhibition of NF- $k B$, MAPKs, and PI3K signaling pathways [143].

On the other hand, preclinical and clinical studies show that kimchi's medicinal benefits might be associated with gut microbiota modulation [125,145]. For example, gut microbiota modulation by kimchi intake is related to this health food's antiobesity role [146]. The correlation of obesity with elevation in the relative abundance of Firmicutes and reduction in the relative abundance of Bacteroidetes phyla in the gut microbial population has been supported by substantial evidence $[147,148]$. In a study, feeding 45 male Sprague-Dawley rats with a diet containing kimchi was associated with an increase in gut microbiota diversity, a decrease in the abundance of Firmicutes, and an increase in the quantity of Bacteroidetes. Also, the number of LAB and butyric acid-producing bacteria was elevated [125]. In another study, feeding mice with a kimchi microbial community raised the frequency of Muribaculaceae and family and reduced the frequency of Coriobacteriaceae, and Erysipelotrichaceae families [146]. Muribaculaceae is negatively associated with obesity indicators, while Coriobacteriaceae and Erysipelotrichaceae are abundant in obese people [146].

Anti-inflammatory and immunomodulatory functions of LAB derived from kimchi through the regulation of gut microbiota have been exhibited in animal models of allergic skin disorders [149]. Atopic dermatitis is an inflammatory skin disorder characterized by $\mathrm{T}$ helper 2 (Th2)-dominated immune responses and an elevated level of immunoglobulin E (IgE) [150]. Administration of Lactobacillus sakei (L. sakei) WIKIM30, a probiotic strain extracted from kimchi, to mice with 2,4-dinitrochlorobenzene-induced atopic dermatitis inhibited Th2 immune response and Th2 related cytokines (IL-4, IL-5, and IL-13), regulated Th1/Th2 balance, induced Tregs differentiation and decreased skin lesions [149]. Dysbiosis of gut microbiota has been reported in atopic dermatitis [149]. Microbiome analysis revealed that the protective function of L. sakei WIKIM30 against atopic dermatitis could be mediated by its effect on gut microbiota. Treatment with this probiotic restored the changes in gut microbiota composition induced by atopic dermatitis toward an elevation in Arthromitus and Ralstonia and a reduction in Ruminococcus abundance [149]. Besides, the administration of live and heat-inactivated L. sakei probio-65, extracted from Kimchi, ameliorated skin inflammation and lesions by reducing serum IgE and/or inhibition of Th2related cytokines [150]. L. plantarum K-1 isolated from kimchi may mitigate inflammation and alleviate allergic diseases by suppressing the TNF- $\alpha$ and IL-4 expression and inhibiting NF- $\kappa B$ activation [151].

Kimchi-derived LAB display potential for alleviating IBD in mice [152,153]. Administration of Lactobacillus paracasei (L. paracasei) LS2, a lactic acid bacterium derived from kimchi, increased CD4+FOXP3+ Treg cells and anti-inflammatory cytokine IL-10 production in mice with colitis. It also decreased IL-6, TNF, and INF- $\gamma$ levels in colon tissue. The colonic activity of myeloperoxidase (MPO) was significantly reduced in mice fed with L. paracasei LS2. Colonic MPO activity indicates neutrophil infiltration and tissue damage [153]. L. mesenteroides and L. sakei are other kimchi-extracted LAB with significant potential for attenuation inflammation in experimental colitis [152]. Figure 2 illustrates the protective effects of fermented cabbage products against inflammatory disorders. 


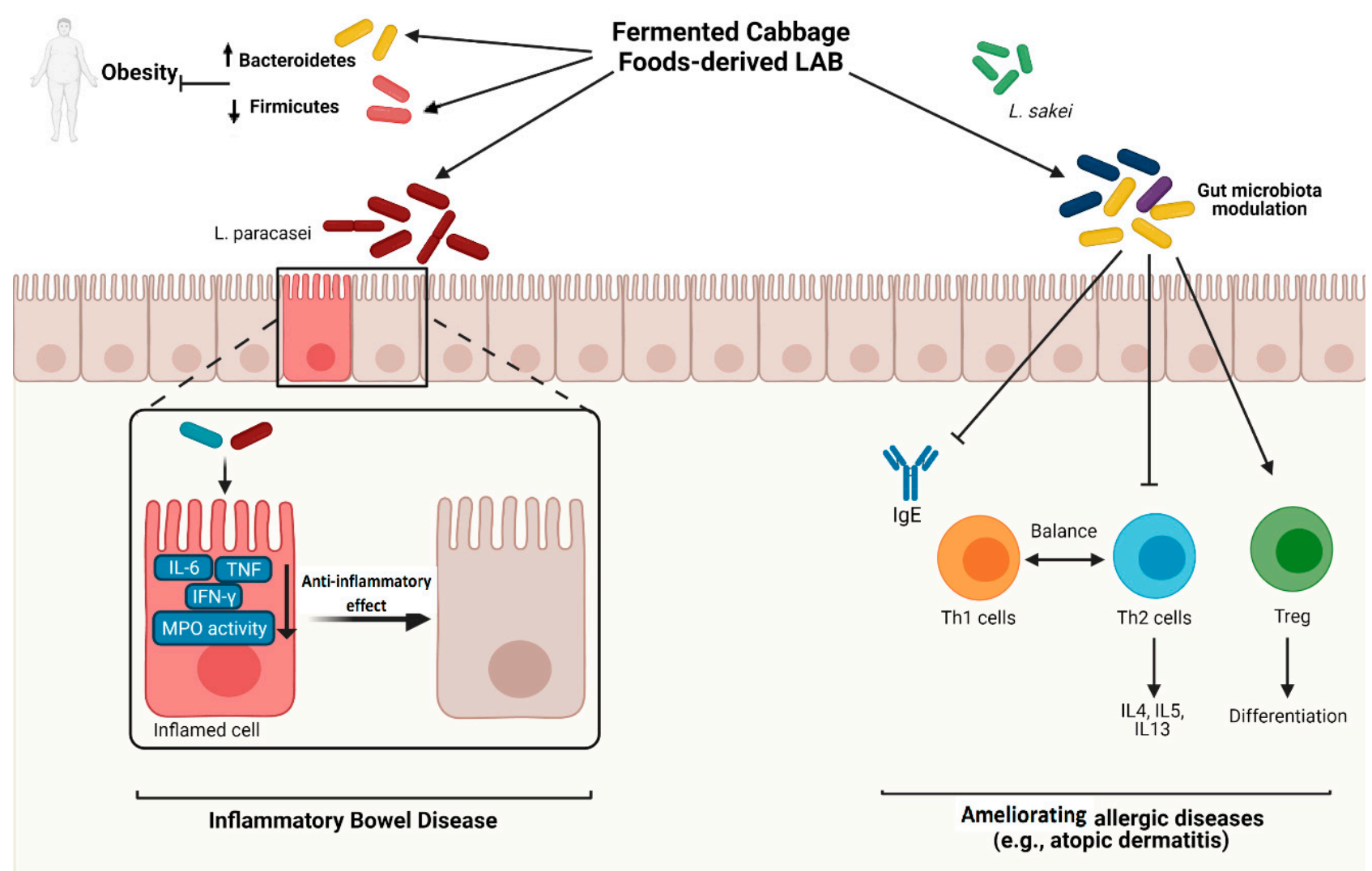

Figure 2. The Protective effect of fermented cabbage foods-derived lactic acid bacteria against inflammatory disorders. $\uparrow:$ increase; $\downarrow$ : decrease; LAB: lactic acid-producing bacteria; IL-6: interleukin-6; TNF: tumor necrosis factor; INF- $\gamma$ : interferon-gamma; MPO: myeloperoxidase; IgE: immunoglobulin E; Th1: T helper 1; Th2: T helper 2; IL-4: interleukin-4; IL-5: interleukin-5; IL-13: interleukin-13; Treg: regulatory T cells. Cre-ated with Biorender.com.

In the clinical setting, Kim et al. (2016) found that kimchi could affect gut microbiota composition for its singular synbiotic content [145]. They examined the effect of low and high kimchi diets on the gut microbiota of 12 females. A substantial decrease in the frequency of class Gammaproteobacteria, which consists of many pathogenic bacteria, was observed in the high kimchi group. Furthermore, a significant increase in the frequency of kimchi LAB, such as L. mesenteroides was reported in participants' fecal samples [145]. Fermented kimchi may also modify metabolic parameters in overweight/obese subjects [154,155]. In a clinical trial, fermented kimchi modified the expression of several genes related to the metabolic pathways and immunity in obese women. It also affected metabolism by changing gut microbial communities which the abundance of Firmicutes decreased while that of Bacteroidetes increased [154].

Fermented cabbage-derived LAB (e.g., L. paracasei) inhibit the pro-inflammatory mediators and inflammatory enzymes, including IL-6, TNF, IFN- $\gamma$, and myeloperoxidase (MPO), and alleviate inflammatory bowel disease. LAB also prevent obesity by modulating gut microbiota toward decreasing Firmicutes' abundance and increasing Bacteroidetes frequency. Furthermore, LAB extracted from fermented cabbage foods (e.g., L. sakei) restore gut microbiota and modulate immune responses by regulating Th1/Th2 balance, inhibiting Th2-related cytokines, inducing Tregs differentiation, and reducing IgE level, alleviating allergic reactions such as atopic dermatitis. Created with Biorender.com (accessed on 29 April 2021). 


\section{Fermented Soy Products}

Soybean is a protein-rich grain and a good source of soluble carbohydrate [156]. Vitamins, minerals, phospholipids, phenolic compounds, and antioxidants are the other valuable soybean components $[157,158]$. This valuable grain is widely used in many traditional fermented dishes. Many Asian countries, including China, Indonesia, India, Vietnam, and Japan, produce different types of fermented soyfoods such as tempeh, miso, natto, douchi, and hawaijar $[159,160]$. Bacteria, yeasts, molds, or a combination of each contribute to the fermentation of soybeans endowing the final products with better texture, enriched flavor, and high nutritional value [161]. Table 1 represents the characteristics, nutritional value, and health benefits of some commonly used fermented soy foods.

Table 1. The characteristics, nutritional value, and health benefits of fermented soy foods.

\begin{tabular}{|c|c|c|c|c|c|}
\hline Product & $\begin{array}{l}\text { Fermentation } \\
\text { Processes }\end{array}$ & $\begin{array}{l}\text { Microorganism } \\
\text { Involved in } \\
\text { Fermentation }\end{array}$ & Nutritional Value & Health Benefits & Ref. \\
\hline Tempe & $\begin{array}{l}\text { It is made in two } \\
\text { steps: bacterial } \\
\text { fermentation of } \\
\text { cooked dehulled } \\
\text { soybeans followed } \\
\text { by solid-state } \\
\text { fermentation by } \\
\text { the mold }\end{array}$ & $\begin{array}{l}\text { Rhizopus oligosporus, } \\
\text { Rhizopus oryzae }\end{array}$ & $\begin{array}{l}\text { High in protein } \\
\text { Rich source of } \\
\text { probiotics, } \\
\text { phytonutrients, } \\
\text { and isoflavones }\end{array}$ & $\begin{array}{l}\text { Inhibition of free } \\
\text { radicals production, } \\
\text { antioxidant activity } \\
\text { Cognitive improvement } \\
\text { Modulation of gut } \\
\text { microbiota in human } \\
\text { toward a healthier } \\
\text { profile }\end{array}$ & [162-166] \\
\hline $\begin{array}{l}\text { Natto } \\
\text { (Itohiki) }\end{array}$ & $\begin{array}{l}\text { Natto is produced } \\
\text { using soaked and } \\
\text { cooked soybeans } \\
\text { fermented by } \\
\text { bacteria for } 24 \mathrm{~h} \text { at } \\
\quad 40^{\circ} \mathrm{C}\end{array}$ & Bacillus natto & $\begin{array}{l}\text { Lower amount } \\
\text { of sugar } \\
\text { Increased proteins } \\
\text { hydrolysis and } \\
\text { digestibility } \\
\text { High amount of } \\
\text { fiber and vitamin } \mathrm{K}, \\
\text { free isoflavones, } \\
\text { and levan }\end{array}$ & $\begin{array}{l}\text { Prevention from blood } \\
\text { clot formation by the } \\
\text { production of } \\
\text { nattokinase, and } \\
\text { therefore prevention } \\
\text { from cardiovascular } \\
\text { diseases } \\
\text { Antioxidant and } \\
\text { antihypertensive } \\
\text { activity } \\
\text { Reduction in bone loss } \\
\text { and promotion of bone } \\
\text { formation in } \\
\text { postmenopausal women } \\
\text { Gut microbiota } \\
\text { modulation }\end{array}$ & [165,167-171], \\
\hline Douchi & $\begin{array}{l}\text { Soaked and steamed } \\
\text { soybeans are } \\
\text { incubated with } \\
\text { Aspergillus spp. for } \\
3-4 \text { days at } 30^{\circ} \mathrm{C}, \\
\text { then after washing } \\
\text { and adding salt, } \\
\text { water, and ginger } \\
\text { spices, the mixture } \\
\text { is incubated for } \\
15 \text { days at } 37^{\circ} \mathrm{C}\end{array}$ & Aspergullus oryzae & $\begin{array}{l}\text { High in protein, } \\
\text { peptides, free and } \\
\text { essential } \\
\text { amino acids } \\
\text { and organic acids }\end{array}$ & $\begin{array}{c}\text { Antioxidative, } \\
\text { antihypertensive, and } \\
\text { antidiabetic activity }\end{array}$ & [172-174] \\
\hline Hawaijar & $\begin{array}{l}\text { Washed, soaked, } \\
\text { and boiled (for } \\
\text { 2-3 h) soybeans are } \\
\text { loosely packed in } \\
\text { the bamboo basket } \\
\text { lined with leaves } \\
\text { and kept for } \\
\text { 2-3 days to be } \\
\text { fermented }\end{array}$ & $\begin{array}{l}\text { Bacillus subtilus, } \\
\text { Bacillus licheniformis, } \\
\text { Bacillus cereus, and a } \\
\text { smaller number of } \\
\text { Staphylococcus spp. }\end{array}$ & $\begin{array}{l}\text { A rich source of } \\
\text { protein, essential } \\
\text { amino acids, and } \\
\text { peptides } \\
\text { High fiber content }\end{array}$ & $\begin{array}{l}\text { Radical scavenging, } \\
\text { antioxidant and } \\
\text { antidiabetic activities }\end{array}$ & [175-177] \\
\hline Miso & $\begin{array}{l}\text { Miso is made by } \\
\text { enzymatic } \\
\text { degradation of } \\
\text { cooked soybeans } \\
\text { with molded rice, } \\
\text { wheat, orbarley, and } \\
\text { a small amount of } \\
\text { water in the } \\
\text { presence of } \\
8-12 \% \text { salt }\end{array}$ & $\begin{array}{c}\text { Aspergullus oryzae, } \\
\text { Pediococcus } \\
\text { halophilus }\end{array}$ & $\begin{array}{l}\text { Rich source of } \\
\text { different vitamins, } \\
\text { including vitamins } \\
\text { B, K, E, folic acid } \\
\text { and also minerals, } \\
\text { amino acids }\end{array}$ & $\begin{array}{l}\text { Protection against } \\
\text { hypertension, stroke, } \\
\text { and some types } \\
\text { of cancer } \\
\text { Antiobesity, antidiabetic } \\
\text { immunomodulatory, } \\
\text { and antioxidant } \\
\text { activities } \\
\text { Gut microbiota } \\
\text { modulation }\end{array}$ & {$[165,169,178,179]$} \\
\hline
\end{tabular}


A large body of research evidence has indicated the protective role of fermented soybeans against inflammatory disorders such as cancer, type- 2 diabetes, cardiovascular diseases, and neurodegenerative diseases $[160,180]$. Isoflavones are mainly responsible for the anti-inflammatory activity of fermented soy products [160]. Genistein, daidzein, and glycitein are the main isoflavones abundantly found in fermented soybeans [181], with significant anti-inflammatory properties [182-184]. For example, the role of isoflavones on the basophils, mast cells, and eosinophils, as the primary mediators of systemic allergic inflammation, has been shown in recent studies [185,186]. Isoflavones protect against allergic inflammatory reactions and modulate immune responses through IgE signaling inhibition and suppressing the Th2 response $[187,188]$. Genistein has been identified as a potent inhibitor of Fce receptor expression on the human leukemic mast cell line [189]. An increase in IgE levels and IgE sensitization to allergens occurs in allergic reactions such as asthma. Following exposure to the antigens, IgE binds to the FcE receptors on mast cells, basophils, and dendritic cells and activates them [190].

Treatment with nanonutraceuticals, a mixture of various metabolites derived from soybean fermented with Bacillus subtilis, including nattokinase, daidzin, genistin, glycitin, and menaquinone-7, showed neuroprotective properties in rats with memory impairment through inhibition of neurobehavioral and neurochemical impairments. This nanonutraceuticals is a potent antioxidant that can be protective against Alzheimer's diseases [191]. The anti-inflammatory effects of two Korean fermented soy foods (doenjang and cheonggukjang) have been explored in high-fat fed rats. These foods exerted anti-inflammatory activity by reducing free radical production, suppressing NF- $\mathrm{kB}$ signaling, and inhibiting COX-2 and iNOS expression [192].

Fermented soy products may mitigate inflammation and modulate immune system responses through modulating gut microbiota. Chronic kidney disease (CKD) is considered a pro-inflammatory condition. Various factors such as increased inflammatory cytokines, oxidative stress, and gut dysbiosis contribute to CKD's inflammatory state [193]. He et al. (2020) observed that dietary intervention with fermented soybean (ImmuBalance), a unique oligo-lactic acid product, or a combination of both reduced inflammatory cytokine levels and acute and chronic inflammation in the kidneys and subsequently decreased inflammation-induced kidney damage and prevented disease progression in mice [193]. The abundance of Clostridium leptum bacteria in gut microbiota was higher in the treatment groups' cecum than the control group [193]. A decrease in the frequency of Clostridium leptum in some inflammatory diseases such as IBD has been reported [194,195]. Fermented soybean also increased the abundance of Bifidobacterium genus and Bacteroides fragilis. Therefore modulation of gut microbiota by dietary intervention might contribute to the prevention of inflammation in CKD [193].

Antidiabetic features of the short-term fermented soybean with Bacillus amyloliquefaciens have been seen in an Asian type 2 diabetic animal model. Feeding rats with this product improved glucose metabolism, insulin secretion, and sensitivity. The number of beneficial gut bacteria such as lactobacillales and Akkermensia muciniphila increased, leading to the maintenance of mucin content, the villi area, and the frequency of goblet cells in the gut [196].

Research evidence has elucidated the health-promoting features of fermented soy in humans as well [197]. Due to the high probiotics content, fermented soy product intake is related to human intestinal health [197]. In a study of 10 healthy subjects, consumption of soymilk fermented with a mixture of microorganism, including L. plantarum, L. casei, Lactococcus lactis, L. mesenteroides, and Saccharomyces florentinus, could increase the frequency of beneficial bacteria, bifidobacteria, and lactobacilli, in the feces of participants, while a decrease in abundance of fecal clostridia was observed [198]. Similar changes in the gut microbiota composition were reported in 28 healthy males and females consuming fermented soy milk (500 mL/day, two weeks) [199].

Besides, recent evidence suggested that short-term fermented soybean intake can be protective against memory impairment and Alzheimer's disease in humans by suppressing 
insulin resistance in the brain, preventing neuroinflammation, and modulating the gutmicrobiome-brain axis [200].

Furthermore, large population-based studies have proved the health benefits of fermented soy in humans. For example, a population-based cohort study conducted by The Japan Public Health Centre-based Prospective Study evaluated the association of soybean product consumption and all-cause and cause-specific mortalities during 15 years. They showed that the higher intake of fermented soy products significantly correlated with a lower risk of mortality. However, there was no significant association between a higher intake of total soy and mortality rate [201].

\section{Conclusions}

Scientific research highlights the significance of gut microbiota-directed interventions by diet enrichment with functional natural products such as probiotics and phytochemicals as a promising strategy to promote immune system performance, modulate inflammatory responses, and improve human health. Fermented fruits, vegetables, and grains enrich our diet with numerous live microorganisms, phytochemicals, and bioactive compounds. These compounds play a key role in the functional and health-promoting properties of fermented products. Due to the high content of phenolic compounds with strong antioxidant activity, fermented blueberries and blackberries may protect against chronic inflammatory disorders by decreasing oxidative stress, modulating inflammatory signaling and responses, and improving immunity. Regarding fermented cabbage products, sauerkraut and kimchi, live LAB are the key player in improving health and preventing chronic diseases through improving a healthy gut microbial balance and modulating inflammatory and immune responses. Fermented soybeans are an excellent source of isoflavones with known anti-inflammatory properties. Furthermore, probiotics found in fermented soy products contribute to the health benefits of these nutritious foods. Overall, growing evidence is strongly supporting the health benefits of fermented plant foods. However, existing evidence has been chiefly generated from in vitro and animal studies, and there exist rare clinical studies in this field. Therefore, the potential role of fermented plant products in human health remains to be determined by randomized, controlled clinical trials.

Author Contributions: R.S. wrote most parts of the paper; F.S. contributed to writing the fermented soy products section; N.A. contributed to writing the fermented blueberries section; R.B. and H.Y.-S. contributed to preparing graphical abstract and figures; C.M. revised and guided the work. All authors have read and agreed to the published version of the manuscript.

Funding: This research received no external funding.

Institutional Review Board Statement: Not applicable.

Informed Consent Statement: Not applicable.

Data Availability Statement: Not applicable.

Acknowledgments: In this Special thanks to the University of Ottawa library.

Conflicts of Interest: The authors declare no conflict of interest.

\section{References}

1. Chen, L.; Deng, H.; Cui, H.; Fang, J.; Zuo, Z.; Deng, J.; Li, Y.; Wang, X.; Zhao, L. Inflammatory responses and inflammationassociated diseases in organs. Oncotarget 2017, 9, 7204-7218. [CrossRef] [PubMed]

2. Pahwa, R.; Goyal, A.; Bansal, P.; Jialal, I. Chronic Inflammation. In StatPearls [Internet]; Updated 20 November 2020; StatPearls Publishing: Treasure Island, FL, USA, 2020. Available online: https:/ /www.ncbi.nlm.nih.gov/books/NBK493173/ (accessed on 30 January 2021).

3. Azab, A.; Nassar, A.; Azab, A.N. Anti-Inflammatory Activity of Natural Products. Molecules 2016, 21, 1321. [CrossRef] [PubMed]

4. Shahbazi, R.; Yasavoli-Sharahi, H.; Alsadi, N.; Ismail, N.; Matar, C. Probiotics in Treatment of Viral Respiratory Infections and Neuroinflammatory Disorders. Molecules 2020, 25, 4891. [CrossRef] [PubMed]

5. Freire, M.O.; Van Dyke, T.E. Natural resolution of inflammation. Periodontol 2000 2013, 63, 149-164. [CrossRef] [PubMed] 
6. Kim, J.H.; Kismali, G.; Gupta, S.C. Natural Products for the Prevention and Treatment of Chronic Inflammatory Diseases: Integrating Traditional Medicine into Modern Chronic Diseases Care. Evid. Based Complementary Altern. Med. 2018, $2018,9837863$. [CrossRef] [PubMed]

7. Dias, D.A.; Urban, S.; Roessner, U. A historical overview of natural products in drug discovery. Metabolites 2012, 2, 303-336. [CrossRef]

8. Che, C.-T.; Zhang, H. Plant Natural Products for Human Health. Int. J. Mol. Sci. 2019, 20, 830. [CrossRef]

9. Ramana, K.V.; Singhal, S.S.; Reddy, A.B. Therapeutic Potential of Natural Pharmacological Agents in the Treatment of Human Diseases. Biomed Res. Int. 2014, 2014, 573452. [CrossRef] [PubMed]

10. Mathur, S.; Hoskins, C. Drug development: Lessons from nature. Biomed. Rep. 2017, 6, 612-614. [CrossRef]

11. Parvez, S.; Malik, K.A.; Ah Kang, S.; Kim, H.Y. Probiotics and their fermented food products are beneficial for health. J. Appl. Microbiol. 2006, 100, 1171-1185. [CrossRef]

12. Rezac, S.; Kok, C.R.; Heermann, M.; Hutkins, R. Fermented Foods as a Dietary Source of Live Organisms. Front. Microbiol. 2018, 9, 1785. [CrossRef]

13. Swain, M.R.; Anandharaj, M.; Ray, R.C.; Rani, R.P. Fermented fruits and vegetables of Asia: A potential source of probiotics. Biotechnol. Res. Int. 2014, 2014, 250424. [CrossRef]

14. Shiby, V.K.; Mishra, H.N. Fermented milks and milk products as functional foods-A review. Crit. Rev. Food Sci. Nutr. 2013, 53, 482-496. [CrossRef] [PubMed]

15. Hur, S.J.; Lee, S.Y.; Kim, Y.-C.; Choi, I.; Kim, G.-B. Effect of fermentation on the antioxidant activity in plant-based foods. Food Chem. 2014, 160, 346-356. [CrossRef] [PubMed]

16. Yeo, S.K.; Ewe, J.A. 5-Effect of fermentation on the phytochemical contents and antioxidant properties of plant foods. In Advances in Fermented Foods and Beverages; Holzapfel, W., Ed.; Woodhead Publishing: Cambridge, UK, 2015; pp. 107-122.

17. Şanlier, N.; Gökcen, B.B.; Sezgin, A.C. Health benefits of fermented foods. Crit. Rev. Food Sci. Nutr. 2019, 59, 506-527. [CrossRef]

18. Peres, C.M.; Peres, C.; Hernández-Mendoza, A.; Malcata, F.X. Review on fermented plant materials as carriers and sources of potentially probiotic lactic acid bacteria-With an emphasis on table olives. Trends Food Sci. Technol. 2012, 26, 31-42. [CrossRef]

19. Nuraida, L. A review: Health promoting lactic acid bacteria in traditional Indonesian fermented foods. Food Sci. Hum. Wellness 2015, 4, 47-55. [CrossRef]

20. Septembre-Malaterre, A.; Remize, F.; Poucheret, P. Fruits and vegetables, as a source of nutritional compounds and phytochemicals: Changes in bioactive compounds during lactic fermentation. Food Res. Int. 2018, 104, 86-99. [CrossRef]

21. Tamang, J.P. Health Benefits of Fermented Foods and Beverages; CRC Press: Boca Raton, FL, USA, 2015.

22. Ray, M.; Ghosh, K.; Singh, S.; Chandra Mondal, K. Folk to functional: An explorative overview of rice-based fermented foods and beverages in India. J. Ethn. Foods 2016, 3, 5-18. [CrossRef]

23. Tamang, J.P. Plant-Based Fermented Foods and Beverages of Asia; CRC: Boca Raton, FL, USA, 2012.

24. Leroy, F.; De Vuyst, L. Lactic acid bacteria as functional starter cultures for the food fermentation industry. Trends Food Sci. Technol. 2004, 15, 67-78. [CrossRef]

25. Corsetti, A.; Perpetuini, G.; Schirone, M.; Tofalo, R.; Suzzi, G. Application of starter cultures to table olive fermentation: An overview on the experimental studies. Front. Microbiol. 2012, 3, 248. [CrossRef] [PubMed]

26. Hammes, W.P. Bacterial starter cultures in food production. Food Biotechnol. 1990, 4, 383-397. [CrossRef]

27. Chiu, H.H.; Tsai, C.C.; Hsih, H.Y.; Tsen, H.Y. Screening from pickled vegetables the potential probiotic strains of lactic acid bacteria able to inhibit the Salmonella invasion in mice. J. Appl. Microbiol. 2008, 104, 605-612. [CrossRef]

28. Marco, M.L.; Heeney, D.; Binda, S.; Cifelli, C.J.; Cotter, P.D.; Foligné, B.; Gänzle, M.; Kort, R.; Pasin, G.; Pihlanto, A.; et al. Health benefits of fermented foods: Microbiota and beyond. Curr. Opin. Biotechnol. 2017, 44, 94-102. [CrossRef] [PubMed]

29. Bell, V.; Ferrão, J.; Pimentel, L.; Pintado, M.; Fernandes, T. One Health, Fermented Foods, and Gut Microbiota. Foods 2018, 7, 195. [CrossRef]

30. Rinninella, E.; Raoul, P.; Cintoni, M.; Franceschi, F.; Miggiano, G.A.D.; Gasbarrini, A.; Mele, M.C. What is the Healthy Gut Microbiota Composition? A Changing Ecosystem across Age, Environment, Diet, and Diseases. Microorganisms 2019, 7, 14. [CrossRef]

31. Ursell, L.K.; Metcalf, J.L.; Parfrey, L.W.; Knight, R. Defining the human microbiome. Nutr. Rev. 2012, 70 (Suppl. 1), S38-S44. [CrossRef]

32. Thursby, E.; Juge, N. Introduction to the human gut microbiota. Biochem. J. 2017, 474, 1823-1836. [CrossRef]

33. Kho, Z.Y.; Lal, S.K. The Human Gut Microbiome-A Potential Controller of Wellness and Disease. Front. Microbiol. 2018, 9, 1835. [CrossRef]

34. Kamada, N.; Seo, S.U.; Chen, G.Y.; Núñez, G. Role of the gut microbiota in immunity and inflammatory disease. Nat. Rev. Immunol. 2013, 13, 321-335. [CrossRef]

35. Belkaid, Y.; Hand, T.W. Role of the microbiota in immunity and inflammation. Cell 2014, 157, 121-141. [CrossRef]

36. Caricilli, A.M.; Castoldi, A.; Câmara, N.O. Intestinal barrier: A gentlemen's agreement between microbiota and immunity. World J. Gastrointest. Pathophysiol. 2014, 5, 18-32. [CrossRef] [PubMed]

37. Pandiyan, P.; Bhaskaran, N.; Zou, M.; Schneider, E.; Jayaraman, S.; Huehn, J. Microbiome Dependent Regulation of Tregs and Th17 Cells in Mucosa. Front. Immunol. 2019, 10, 426. [CrossRef] 
38. Kamada, N.; Núñez, G. Role of the gut microbiota in the development and function of lymphoid cells. J. Immunol. 2013, 190, 1389-1395. [CrossRef] [PubMed]

39. Lee, N.; Kim, W.-U. Microbiota in T-cell homeostasis and inflammatory diseases. Exp. Mol. Med. 2017, 49, e340. [CrossRef] [PubMed]

40. Zhao, J.; Gong, L.; Wu, L.; She, S.; Liao, Y.; Zheng, H.; Zhao, Z.; Liu, G.; Yan, S. Immunomodulatory effects of fermented fig (Ficus carica L.) fruit extracts on cyclophosphamide-treated mice. J. Funct. Foods 2020, 75, 104219. [CrossRef]

41. Birhanu, B.T.; Kim, J.-Y.; Hossain, M.A.; Choi, J.-W.; Lee, S.-P.; Park, S.-C. An in vivo immunomodulatory and anti-inflammatory study of fermented Dendropanax morbifera Léveille leaf extract. BMC Complementary Altern. Med. 2018, 18, 222. [CrossRef]

42. Zulkawi, N.; Ng, K.H.; Zamberi, R.; Yeap, S.K.; Satharasinghe, D.; Jaganath, I.B.; Jamaluddin, A.B.; Tan, S.W.; Ho, W.Y.; Alitheen, N.B.; et al. In vitro characterization and in vivo toxicity, antioxidant and immunomodulatory effect of fermented foods; Xeniji ${ }^{\mathrm{TM}}$. BMC Complementary Altern. Med. 2017, 17, 344. [CrossRef]

43. Forsythe, P. Probiotics and lung immune responses. Ann. Am. Thorac. Soc. 2014, 11 (Suppl. 1), S33-S37. [CrossRef] [PubMed]

44. Mortaz, E.; Adcock, I.M.; Folkerts, G.; Barnes, P.J.; Paul Vos, A.; Garssen, J. Probiotics in the management of lung diseases. Mediat. Inflamm 2013, 2013, 751068. [CrossRef]

45. Westfall, S.; Lomis, N.; Kahouli, I.; Dia, S.Y.; Singh, S.P.; Prakash, S. Microbiome, probiotics and neurodegenerative diseases: Deciphering the gut brain axis. Cell. Mol. Life Sci. CMLS 2017, 74, 3769-3787. [CrossRef] [PubMed]

46. Lavasani, S.; Dzhambazov, B.; Nouri, M.; Fåk, F.; Buske, S.; Molin, G.; Thorlacius, H.; Alenfall, J.; Jeppsson, B.; Weström, B. A novel probiotic mixture exerts a therapeutic effect on experimental autoimmune encephalomyelitis mediated by IL-10 producing regulatory T cells. PLoS ONE 2010, 5, e9009. [CrossRef]

47. Feng, Y.; Huang, Y.; Wang, Y.; Wang, P.; Song, H.; Wang, F. Antibiotics induced intestinal tight junction barrier dysfunction is associated with microbiota dysbiosis, activated NLRP3 inflammasome and autophagy. PLoS ONE 2019, 14, e0218384. [CrossRef]

48. Zhang, S.; Chen, D.C. Facing a new challenge: The adverse effects of antibiotics on gut microbiota and host immunity. Chin. Med. J. 2019, 132, 1135-1138. [CrossRef] [PubMed]

49. Yahfoufi, N.; Mallet, J.; Graham, E.; Matar, C. Role of probiotics and prebiotics in immunomodulation. Curr. Opin. Food Sci. 2018, 20, 82-91. [CrossRef]

50. Bermudez-Brito, M.; Plaza-Díaz, J.; Muñoz-Quezada, S.; Gómez-Llorente, C.; Gil, A. Probiotic mechanisms of action. Ann. Nutr. Metab. 2012, 61, 160-174. [CrossRef] [PubMed]

51. Wang, K.; Dong, H.; Qi, Y.; Pei, Z.; Yi, S.; Yang, X.; Zhao, Y.; Meng, F.; Yu, S.; Zhou, T.; et al. Lactobacillus casei regulates differentiation of Th17/Treg cells to reduce intestinal inflammation in mice. Can. J. Vet. Res. Rev. Can. Rech. Vet. 2017, 81, 122-128.

52. Selhub, E.M.; Logan, A.C.; Bested, A.C. Fermented foods, microbiota, and mental health: Ancient practice meets nutritional psychiatry. J. Physiol. Anthropol. 2014, 33, 2. [CrossRef]

53. Feng, Y.; Zhang, M.; Mujumdar, A.S.; Gao, Z. Recent research process of fermented plant extract: A review. Trends Food Sci. Technol. 2017, 65, 40-48. [CrossRef]

54. Kim, B.; Hong, V.M.; Yang, J.; Hyun, H.; Im, J.J.; Hwang, J.; Yoon, S.; Kim, J.E. A Review of Fermented Foods with Beneficial Effects on Brain and Cognitive Function. Prev. Nutr. Food Sci. 2016, 21, 297-309. [CrossRef] [PubMed]

55. Aruoma, O.I.; Somanah, J.; Bourdon, E.; Rondeau, P.; Bahorun, T. Diabetes as a risk factor to cancer: Functional role of fermented papaya preparation as phytonutraceutical adjunct in the treatment of diabetes and cancer. Mutat. Res. Fundam. Mol. Mech. Mutagenes. 2014, 768, 60-68. [CrossRef]

56. Wilburn, J.; Ryan, E. Fermented foods in health promotion and disease prevention: An overview. In Fermented Foods in Health and Disease Prevention; Elsevier: Amsterdam, The Netherlands, 2017; pp. 3-19.

57. Benítez-Páez, A.; Sanz, Y. Chapter 8-From Bacterial Genomics to Human Health. In Fermented Foods in Health and Disease Prevention; Frias, J., Martinez-Villaluenga, C., Peñas, E., Eds.; Academic Press: Boston, MA, USA, 2017; pp. $159-172$.

58. Basu, A.; Rhone, M.; Lyons, T.J. Berries: Emerging impact on cardiovascular health. Nutr. Rev. 2010, 68, 168-177. [CrossRef]

59. Seeram, N.P. Emerging Research Supporting the Positive Effects of Berries on Human Health and Disease Prevention. J. Agric. Food Chem. 2012, 60, 5685-5686. [CrossRef] [PubMed]

60. Gopalan, A.; Reuben, S.C.; Ahmed, S.; Darvesh, A.S.; Hohmann, J.; Bishayee, A. The health benefits of blackcurrants. Food Funct. 2012, 3, 795-809. [CrossRef]

61. Lavefve, L.; Howard, L.R.; Carbonero, F. Berry polyphenols metabolism and impact on human gut microbiota and health. Food Funct. 2020, 11, 45-65. [CrossRef] [PubMed]

62. Vuong, T.; Martin, L.; Matar, C. Antioxidant activity of fermented berry juices and their effects on nitric oxide and tumor necrosis factor-alpha production in macrophages 264.7 gamma no(-) cell line. J. Food Biochem. 2006, 30, 249-268. [CrossRef]

63. Vuong, T.; Martineau, L.C.; Ramassamy, C.; Matar, C.; Haddad, P.S. Fermented Canadian lowbush blueberry juice stimulates glucose uptake and AMP-activated protein kinase in insulin-sensitive cultured muscle cells and adipocytes. Can. J. Physiol. Pharmacol. 2007, 85, 956-965. [CrossRef] [PubMed]

64. Kristo, A.S.; Klimis-Zacas, D.; Sikalidis, A.K. Protective role of dietary berries in cancer. Antioxidants 2016, 5, 37. [CrossRef] [PubMed]

65. Boath, A.S.; Grussu, D.; Stewart, D.; McDougall, G.J. Berry Polyphenols Inhibit Digestive Enzymes: A Source of Potential Health Benefits? Food Dig. 2012, 3, 1-7. [CrossRef] 
66. Johnson, M.H.; de Mejia, E.G.; Fan, J.; Lila, M.A.; Yousef, G.G. Anthocyanins and proanthocyanidins from blueberry-blackberry fermented beverages inhibit markers of inflammation in macrophages and carbohydrate-utilizing enzymes in vitro. Mol. Nutr. Food Res. 2013, 57, 1182-1197. [CrossRef]

67. Martin, L.J.; Matar, C. Increase of antioxidant capacity of the lowbush blueberry (Vaccinium angustifolium) during fermentation by a novel bacterium from the fruit microflora. J. Sci. Food Agric. 2005, 85, 1477-1484. [CrossRef]

68. Johnson, M.H.; Lucius, A.; Meyer, T.; Gonzalez de Mejia, E. Cultivar Evaluation and Effect of Fermentation on Antioxidant Capacity and in Vitro Inhibition of $\alpha$-Amylase and $\alpha$-Glucosidase by Highbush Blueberry (Vaccinium corombosum). J. Agric. Food Chem. 2011, 59, 8923-8930. [CrossRef] [PubMed]

69. Linkner, E.; Humphreys, C. Chapter 32-Insulin Resistance and the Metabolic Syndrome. In Integrative Medicine, 4th ed.; Rakel, D., Ed.; Elsevier: Amsterdam, The Netherlands, 2018; pp. 320-333.e325.

70. Kalt, W.; Cassidy, A.; Howard, L.R.; Krikorian, R.; Stull, A.J.; Tremblay, F.; Zamora-Ros, R. Recent Research on the Health Benefits of Blueberries and Their Anthocyanins. Adv. Nutr. 2020, 11, 224-236. [CrossRef] [PubMed]

71. Zorzi, M.; Gai, F.; Medana, C.; Aigotti, R.; Morello, S.; Peiretti, P.G. Bioactive Compounds and Antioxidant Capacity of Small Berries. Foods 2020, 9, 623. [CrossRef] [PubMed]

72. Vuong, T.; Mallet, J.-F.; Ouzounova, M.; Rahbar, S.; Hernandez-Vargas, H.; Herceg, Z.; Matar, C. Role of a polyphenol-enriched preparation on chemoprevention of mammary carcinoma through cancer stem cells and inflammatory pathways modulation. $J$. Transl. Med. 2016, 14, 13. [CrossRef]

73. Zhang, Y.; Liu, W.; Wei, Z.; Yin, B.; Man, C.; Jiang, Y. Enhancement of functional characteristics of blueberry juice fermented by Lactobacillus plantarum. LWT 2020, 110590. [CrossRef]

74. Vuong, T.; Benhaddou-Andaloussi, A.; Brault, A.; Harbilas, D.; Martineau, L.C.; Vallerand, D.; Ramassamy, C.; Matar, C.; Haddad, P.S. Antiobesity and antidiabetic effects of biotransformed blueberry juice in KKAy mice. Int. J. Obes. 2009, 33, 1166-1173. [CrossRef]

75. Vuong, T.; Matar, C.; Ramassamy, C.; Haddad, P.S. Biotransformed blueberry juice protects neurons from hydrogen peroxideinduced oxidative stress and mitogen-activated protein kinase pathway alterations. Br. J. Nutr. 2010, 104, 656-663. [CrossRef] [PubMed]

76. Yücel, G.; Zhao, Z.; El-Battrawy, I.; Lan, H.; Lang, S.; Li, X.; Buljubasic, F.; Zimmermann, W.-H.; Cyganek, L.; Utikal, J.; et al. Lipopolysaccharides induced inflammatory responses and electrophysiological dysfunctions in human-induced pluripotent stem cell derived cardiomyocytes. Sci. Rep. 2017, 7, 2935. [CrossRef]

77. Peñas, E.; Martinez-Villaluenga, C.; Frias, J. Chapter 24-Sauerkraut: Production, Composition, and Health Benefits. In Fermented Foods in Health and Disease Prevention; Frias, J., Martinez-Villaluenga, C., Peñas, E., Eds.; Academic Press: Boston, MA, USA, 2017; pp. 557-576.

78. Cordeiro Caillot, A.R.; de Lacerda Bezerra, I.; Palhares, L.C.G.F.; Santana-Filho, A.P.; Chavante, S.F.; Sassaki, G.L. Structural characterization of blackberry wine polysaccharides and immunomodulatory effects on LPS-activated RAW 264.7 macrophages. Food Chem. 2018, 257, 143-149. [CrossRef]

79. Moilanen, E.; Vapaatalo, H. Nitric Oxide in Inflammation and Immune Response. Ann. Med. 1995, 27, 359-367. [CrossRef]

80. Liu, B.; Gao, H.M.; Wang, J.Y.; Jeohn, G.H.; Cooper, C.L.; Hong, J.S. Role of nitric oxide in inflammation-mediated neurodegeneration. Ann. N. Y. Acad. Sci. 2002, 962, 318-331. [CrossRef] [PubMed]

81. Achari, A.E.; Jain, S.K. Adiponectin, a Therapeutic Target for Obesity, Diabetes, and Endothelial Dysfunction. Int. J. Mol. Sci. 2017, 18, 1321. [CrossRef]

82. Bruun, J.M.; Lihn, A.S.; Verdich, C.; Pedersen, S.B.; Toubro, S.; Astrup, A.; Richelsen, B. Regulation of adiponectin by adipose tissue-derived cytokines: In vivo and in vitro investigations in humans. Am. J. Physiol. Endocrinol. Metab. 2003, 285, E527-E533. [CrossRef] [PubMed]

83. Ryu, J.-Y.; Kang, H.R.; Cho, S.K. Changes Over the Fermentation Period in Phenolic Compounds and Antioxidant and Anticancer Activities of Blueberries Fermented by Lactobacillus plantarum. J. Food Sci. 2019, 84, 2347-2356. [CrossRef]

84. Cheng, Y.; Wu, T.; Chu, X.; Tang, S.; Cao, W.; Liang, F.; Fang, Y.; Pan, S.; Xu, X. Fermented blueberry pomace with antioxidant properties improves fecal microbiota community structure and short chain fatty acids production in an in vitro mode. LWT 2020, 125, 109260. [CrossRef]

85. Cheng, Y.; Tang, S.; Huang, Y.; Liang, F.; Fang, Y.; Pan, S.; Wu, T.; Xu, X. Lactobacillus casei-fermented blueberry pomace augments sIgA production in high-fat diet mice by improving intestinal microbiota. Food Funct. 2020, 11, 6552-6564. [CrossRef] [PubMed]

86. Song, B.; Zheng, C.; Zha, C.; Hu, S.; Yang, X.; Wang, L.; Xiao, H. Dietary leucine supplementation improves intestinal health of mice through intestinal SIgA secretion. J. Appl. Microbiol. 2020, 128, 574-583. [CrossRef]

87. Cheng, Y.; Wu, T.; Tang, S.; Liang, F.; Fang, Y.; Cao, W.; Pan, S.; Xu, X. Fermented blueberry pomace ameliorates intestinal barrier function through the NF-kB-MLCK signaling pathway in high-fat diet mice. Food Funct. 2020, 11, 3167-3179. [CrossRef]

88. Ma, T.Y.; Boivin, M.A.; Ye, D.; Pedram, A.; Said, H.M. Mechanism of TNF- $\alpha$ modulation of Caco-2 intestinal epithelial tight junction barrier: Role of myosin light-chain kinase protein expression. Am. J. Physiol. Gastrointest. Liver Physiol. 2005, 288, G422-G430. [CrossRef] [PubMed]

89. Ahrén, I.L.; Xu, J.; Önning, G.; Olsson, C.; Ahrné, S.; Molin, G. Antihypertensive activity of blueberries fermented by Lactobacillus plantarum DSM 15313 and effects on the gut microbiota in healthy rats. Clin. Nutr. 2015, 34, 719-726. [CrossRef] 
90. Xu, J.; Ahrén, I.L.; Prykhodko, O.; Olsson, C.; Ahrné, S.; Molin, G. Intake of Blueberry Fermented by Lactobacillus plantarum Affects the Gut Microbiota of L-NAME Treated Rats. Evid. Based Complement Altern. Med. 2013, 2013, 809128. [CrossRef] [PubMed]

91. Canfora, E.E.; Jocken, J.W.; Blaak, E.E. Short-chain fatty acids in control of body weight and insulin sensitivity. Nat. Rev. Endocrinol. 2015, 11, 577-591. [CrossRef] [PubMed]

92. Overall, J.; Bonney, S.A.; Wilson, M.; Beermann, A.; Grace, M.H.; Esposito, D.; Lila, M.A.; Komarnytsky, S. Metabolic Effects of Berries with Structurally Diverse Anthocyanins. Int. J. Mol. Sci. 2017, 18, 422. [CrossRef] [PubMed]

93. Kaume, L.; Howard, L.R.; Devareddy, L. The Blackberry Fruit: A Review on Its Composition and Chemistry, Metabolism and Bioavailability, and Health Benefits. J. Agric. Food Chem. 2012, 60, 5716-5727. [CrossRef]

94. Mudnic, I.; Budimir, D.; Modun, D.; Gunjaca, G.; Generalic, I.; Skroza, D.; Katalinic, V.; Ljubenkov, I.; Boban, M. Antioxidant and vasodilatory effects of blackberry and grape wines. J. Med. Food 2012, 15, 315-321. [CrossRef]

95. Pucel, N.W. Improvement of Functional Bioactivity in Pear: Blackberry Synergies with Lactic Acid Fermentation for Type 2 Diabetes and Hypertension Management. Master's thesis, University of Massachusetts Amherst, Amherst, MA, USA, 2013.

96. Joh, Y.; Maness, N.; McGlynn, W. Antioxidant Properties of "Natchez" and "Triple Crown" Blackberries Using Korean Traditional Winemaking Techniques. Int. J. Food Sci. 2017, 2017, 5468149. [CrossRef] [PubMed]

97. Johnson, M.H.; Wallig, M.; Luna Vital, D.A.; de Mejia, E.G. Alcohol-free fermented blueberry-blackberry beverage phenolic extract attenuates diet-induced obesity and blood glucose in C57BL/6J mice. J. Nutr. Biochem. 2016, 31, 45-59. [CrossRef] [PubMed]

98. Sarvottam, K.; Yadav, R.K. Obesity-related inflammation \& cardiovascular disease: Efficacy of a yoga-based lifestyle intervention. Indian J. Med. Res. 2014, 139, 822-834. [PubMed]

99. Bai, Y.; Sun, Q. Macrophage recruitment in obese adipose tissue. Obes. Rev. 2015, 16, 127-136. [CrossRef]

100. Garcia-Diaz, D.F.; Johnson, M.H.; de Mejia, E.G. Anthocyanins from fermented berry beverages inhibit inflammation-related adiposity response in vitro. J. Med. Food 2014, 18, 489-496. [CrossRef]

101. Chen, M.; Zhang, G.; Yi, M.; Chen, X.; Li, J.; Xie, H.; Chen, X. Effect of UVA irradiation on proliferation and NO/iNOS system of human skin fibroblast. Zhong Nan Da Xue Xue Bao Yi Xue Ban J. Cent. South Univ. Med Sci. 2009, 34, 705-711.

102. Surowiak, P.; Gansukh, T.; Donizy, P.; Halon, A.; Rybak, Z. Increase in cyclooxygenase-2 (COX-2) expression in keratinocytes and dermal fibroblasts in photoaged skin. J. Cosmet. Dermatol. 2014, 13, 195-201. [CrossRef] [PubMed]

103. Kim, H.-R.; Jeong, D.-H.; Kim, S.; Lee, S.-W.; Sin, H.-S.; Yu, K.-Y.; Jeong, S.-I.; Kim, S.-Y. Fermentation of Blackberry with L. plantarum JBMI F5 Enhance the Protection Effect on UVB-Mediated Photoaging in Human Foreskin Fibroblast and Hairless Mice through Regulation of MAPK/NF-kB Signaling. Nutrients 2019, 11, 2429. [CrossRef] [PubMed]

104. Bigot, N.; Beauchef, G.; Hervieu, M.; Oddos, T.; Demoor, M.; Boumediene, K.; Galéra, P. NF-kB accumulation associated with COL1A1 transactivators defects during chronological aging represses type I collagen expression through a-112/-61-bp region of the COL1A1 promoter in human skin fibroblasts. J. Investig. Dermatol. 2012, 132, 2360-2367. [CrossRef] [PubMed]

105. Tanaka, K.; Asamitsu, K.; Uranishi, H.; Iddamalgoda, A.; Ito, K.; Kojima, H.; Okamoto, T. Protecting skin photoaging by NF-кB inhibitor. Curr. Drug Metab. 2010, 11, 431-435. [CrossRef]

106. Marques, C.; Fernandes, I.; Meireles, M.; Faria, A.; Spencer, J.P.E.; Mateus, N.; Calhau, C. Gut microbiota modulation accounts for the neuroprotective properties of anthocyanins. Sci. Rep. 2018, 8, 11341. [CrossRef]

107. Park, S.; Cho, S.M.; Jin, B.R.; Yang, H.J.; Yi, Q.J. Mixture of blackberry leaf and fruit extracts alleviates non-alcoholic steatosis, enhances intestinal integrity, and increases Lactobacillus and Akkermansia in rats. Exp. Biol. Med. 2019, 244, 1629-1641. [CrossRef]

108. Cartea, M.E.; Francisco, M.; Soengas, P.; Velasco, P. Phenolic compounds in Brassica vegetables. Molecules 2010, 16, 251-280. [CrossRef]

109. Dimidi, E.; Cox, S.R.; Rossi, M.; Whelan, K. Fermented Foods: Definitions and Characteristics, Impact on the Gut Microbiota and Effects on Gastrointestinal Health and Disease. Nutrients 2019, 11, 1806. [CrossRef]

110. Di Cagno, R.; Filannino, P.; Gobbetti, M. Fermented Foods: Fermented Vegetables and Other Products. In Encyclopedia of Food and Health; Caballero, B., Finglas, P.M., Toldrá, F., Eds.; Academic Press: Oxford, UK, 2016; pp. 668-674.

111. Montaño, A.; Sánchez, A.H.; Beato, V.M.; López-López, A.; de Castro, A. Pickling. In Encyclopedia of Food and Health; Caballero, B., Finglas, P.M., Toldrá, F., Eds.; Academic Press: Oxford, UK, 2016; pp. 369-374.

112. Kwon, D.Y.; Nyakudya, E.; Jeong, Y.S. Fermentation: Food Products. In Encyclopedia of Agriculture and Food Systems; Van Alfen, N.K., Ed.; Academic Press: Oxford, UK, 2014; pp. 113-123.

113. Simon Sarkadi, L. Chapter 27-Biogenic Amines in Fermented Foods and Health Implications. In Fermented Foods in Health and Disease Prevention; Frias, J., Martinez-Villaluenga, C., Peñas, E., Eds.; Academic Press: Boston, MA, USA, 2017 ; pp. 625-651.

114. Di Cagno, R.; Coda, R. Fermented foods I Fermented Vegetable Products. In Encyclopedia of Food Microbiology, 2nd ed.; Batt, C.A., Tortorello, M.L., Eds.; Academic Press: Oxford, UK, 2014; pp. 875-883.

115. Peñas, E.; Martinez-Villaluenga, C.; Frias, J.; Sánchez-Martínez, M.J.; Pérez-Corona, M.T.; Madrid, Y.; Cámara, C.; Vidal-Valverde, C. Se improves indole glucosinolate hydrolysis products content, Se-methylselenocysteine content, antioxidant capacity and potential anti-inflammatory properties of sauerkraut. Food Chem. 2012, 132, 907-914. [CrossRef]

116. Peñas, E.; Pihlava, J.M.; Vidal-Valverde, C.; Frias, J. Influence of fermentation conditions of Brassica oleracea L. var. capitata on the volatile glucosinolate hydrolysis compounds of sauerkrauts. LWT Food Sci. Technol. 2012, 48, 16-23. [CrossRef] 
117. Martinez-Villaluenga, C.; Peñas, E.; Sidro, B.; Ullate, M.; Frias, J.; Vidal-Valverde, C. White cabbage fermentation improves ascorbigen content, antioxidant and nitric oxide production inhibitory activity in LPS-induced macrophages. LWT Food Sci. Technol. 2012, 46, 77-83. [CrossRef]

118. Wagner, A.E.; Boesch-Saadatmandi, C.; Dose, J.; Schultheiss, G.; Rimbach, G. Anti-inflammatory potential of allyl-isothiocyanaterole of Nrf2, NF-кB and microRNA-155. J. Cell. Mol. Med. 2012, 16, 836-843. [CrossRef] [PubMed]

119. Feng, J.; Liu, P.; Yang, X.; Zhao, X. Screening of immunomodulatory and adhesive Lactobacillus with antagonistic activities against Salmonella from fermented vegetables. World J. Microbiol. Biotechnol. 2015, 31, 1947-1954. [CrossRef]

120. Beganović, J.; Kos, B.; Leboš Pavunc, A.; Uroić, K.; Jokić, M.; Šušković, J. Traditionally produced sauerkraut as source of autochthonous functional starter cultures. Microbiol. Res. 2014, 169, 623-632. [CrossRef] [PubMed]

121. Touret, T.; Oliveira, M.; Semedo-Lemsaddek, T. Putative probiotic lactic acid bacteria isolated from sauerkraut fermentations. PLoS ONE 2018, 13, e0203501. [CrossRef] [PubMed]

122. Tsai, Y.-T.; Cheng, P.-C.; Pan, T.-M. The immunomodulatory effects of lactic acid bacteria for improving immune functions and benefits. Appl. Microbiol. Biotechnol. 2012, 96, 853-862. [CrossRef]

123. Ai, C.; Ma, N.; Zhang, Q.; Wang, G.; Liu, X.; Tian, F.; Chen, P.; Chen, W. Immunomodulatory Effects of Different Lactic Acid Bacteria on Allergic Response and Its Relationship with In Vitro Properties. PLoS ONE 2016, 11, e0164697. [CrossRef]

124. Zubaidah, E.; Susanti, I.; Yuwono, S.S.; Rahayu, A.P.; Srianta, I.; Tewfik, I. The combined impact of sauerkraut with Leuconostoc mesenteroides to enhance immunomodulatory activity in Escherichia coli-infected mice. Eur. Food Res. Technol. 2020, 246, 1889-1893. [CrossRef]

125. Sun, S.; He, M.; VanPatten, S.; Al-Abed, Y. Mechanistic insights into high mobility group box-1 (HMGb1)-induced Toll-like receptor 4 (TLR4) dimer formation. J. Biomol. Struct. Dyn. 2019, 37, 3721-3730. [CrossRef]

126. Mei, H.-C.; Liu, Y.-W.; Chiang, Y.-C.; Chao, S.-H.; Mei, N.-W.; Liu, Y.-W.; Tsai, Y.-C. Immunomodulatory Activity of Lactococcus lactis A17 from Taiwan Fermented Cabbage in OVA-Sensitized BALB/c Mice. Evid. Based Complement Altern. Med. 2013, 2013, 287803. [CrossRef] [PubMed]

127. Raak, C.; Ostermann, T.; Boehm, K.; Molsberger, F. Regular consumption of sauerkraut and its effect on human health: A bibliometric analysis. Glob. Adv. Health Med. 2014, 3, 12-18. [CrossRef]

128. Nielsen, E.S.; Garnås, E.; Jensen, K.J.; Hansen, L.H.; Olsen, P.S.; Ritz, C.; Krych, L.; Nielsen, D.S. Lacto-fermented sauerkraut improves symptoms in IBS patients independent of product pasteurisation-A pilot study. Food Funct. 2018, 9, 5323-5335. [CrossRef] [PubMed]

129. Peters, A.; Krumbholz, P.; Jäger, E.; Heintz-Buschart, A.; Çakir, M.V.; Rothemund, S.; Gaudl, A.; Ceglarek, U.; Schöneberg, T.; Stäubert, C. Metabolites of lactic acid bacteria present in fermented foods are highly potent agonists of human hydroxycarboxylic acid receptor 3. PLoS Genet. 2019, 15, e1008145. [CrossRef]

130. Park, K.-Y.; Jeong, J.-K.; Lee, Y.-E.; Daily III, J.W. Health benefits of kimchi (Korean fermented vegetables) as a probiotic food. J. Med. Food 2014, 17, 6-20. [CrossRef] [PubMed]

131. Park, K.Y.; Kim, H.Y.; Jeong, J.K. Chapter 20-Kimchi and Its Health Benefits. In Fermented Foods in Health and Disease Prevention; Frias, J., Martinez-Villaluenga, C., Peñas, E., Eds.; Academic Press: Boston, MA, USA, 2017; pp. 477-502.

132. Noh, B.-S.; Seo, H.-Y.; Park, W.-S.; Oh, S. Chapter 19—Safety of Kimchi. In Regulating Safety of Traditional and Ethnic Foods; Prakash, V., Martín-Belloso, O., Keener, L., Astley, S., Braun, S., McMahon, H., Lelieveld, H., Eds.; Academic Press: San Diego, CA, USA, 2016; pp. 369-380.

133. Lee, S.H.; Whon, T.W.; Roh, S.W.; Jeon, C.O. Unraveling microbial fermentation features in kimchi: From classical to meta-omics approaches. Appl. Microbiol. Biotechnol. 2020, 104, 7731-7744. [CrossRef]

134. Kim, J.; Bang, J.; Beuchat, L.R.; Kim, H.; Ryu, J.-H. Controlled fermentation of kimchi using naturally occurring antimicrobial agents. Food Microbiol. 2012, 32, 20-31. [CrossRef]

135. Lee, C.H.; Lee, G.I. Safety of Food and Beverages: Safety of Regional Specialities-Korean Fermented Foods. In Encyclopedia of Food Safety; Motarjemi, Y., Ed.; Academic Press: Waltham, MA, USA, 2014; pp. 462-469.

136. Park, K.-Y.; Jeong, J.-K. Chapter 26-Kimchi (Korean Fermented Vegetables) as a Probiotic Food. In Probiotics, Prebiotics, and Synbiotics; Watson, R.R., Preedy, V.R., Eds.; Academic Press: Cambridge, MA, USA, 2016; pp. 391-408.

137. Patra, J.K.; Das, G.; Paramithiotis, S.; Shin, H.-S. Kimchi and Other Widely Consumed Traditional Fermented Foods of Korea: A Review. Front. Microbiol. 2016, 7, 1493. [CrossRef]

138. Kim, B.; Mun, E.G.; Kim, D.; Kim, Y.; Park, Y.; Hae-Jeung, L.; Youn-Soo, C. A survey of research papers on the health benefits of kimchi and kimchi lactic acid bacteria. J. Nutr. Health 2018, 51, 1-13. [CrossRef]

139. Dass, C.R. Starter Cultures I Importance of Selected Genera. In Encyclopedia of Food Microbiology; Robinson, R.K., Ed.; Elsevier: Oxford, UK, 1999; pp. 2095-2100.

140. Park, K.; Rhee, S.; Shi, J.; Ho, C.; Shahidi, F. Asian Functional Foods; CRC Press/Taylor and Francis Group: Boca Raton, FL, USA, 2005.

141. Ahn, S. The Effect of Kimchi Powder Supplement on the Body Weight Reduction of Obese Adult Women. Master's Thesis, Pusan National University, Pusan, Korea, 2007.

142. Kim, B.K.; Choi, J.M.; Kang, S.A.; Park, K.Y.; Cho, E.J. Antioxidative effects of Kimchi under different fermentation stage on radical-induced oxidative stress. Nutr. Res. Pract. 2014, 8, 638-643. [CrossRef] [PubMed] 
143. Jeong, J.-W.; Choi, I.-W.; Jo, G.-H.; Kim, G.-Y.; Kim, J.; Suh, H.; Ryu, C.-H.; Kim, W.-J.; Park, K.-Y.; Choi, Y.H. Antiinflammatory effects of 3-(4'-Hydroxyl-3', $5^{\prime}$-dimethoxyphenyl) propionic acid, an active component of korean cabbage kimchi, in lipopolysaccharide-stimulated bv2 microglia. J. Med. Food 2015, 18, 677-684. [CrossRef] [PubMed]

144. Kim, H.-J.; Noh, J.-S.; Song, Y.O. Beneficial Effects of Kimchi, a Korean Fermented Vegetable Food, on Pathophysiological Factors Related to Atherosclerosis. J. Med. Food 2018, 21, 127-135. [CrossRef] [PubMed]

145. Kim, J.; Choi, E.; Hong, Y.; Song, Y.; Han, J.; Lee, S.; Han, E.; Kim, T.; Choi, I.; Cho, K. Changes in Korean adult females' intestinal microbiota resulting from kimchi intake. J. Nutr. Food Sci. 2016, 6, 4172.

146. Park, S.-E.; Kwon, S.J.; Cho, K.-M.; Seo, S.-H.; Kim, E.-J.; Unno, T.; Bok, S.-H.; Park, D.-H.; Son, H.-S. Intervention with kimchi microbial community ameliorates obesity by regulating gut microbiota. J. Microbiol. 2020, 58, 859-867. [CrossRef] [PubMed]

147. Million, M.; Lagier, J.C.; Yahav, D.; Paul, M. Gut bacterial microbiota and obesity. Clin. Microbiol. Infect. 2013, 19, 305-313. [CrossRef] [PubMed]

148. Ley, R.E.; Bäckhed, F.; Turnbaugh, P.; Lozupone, C.A.; Knight, R.D.; Gordon, J.I. Obesity alters gut microbial ecology. Proc. Natl. Acad. Sci. USA 2005, 102, 11070-11075. [CrossRef]

149. Kwon, M.-S.; Lim, S.K.; Jang, J.-Y.; Lee, J.; Park, H.K.; Kim, N.; Yun, M.; Shin, M.-Y.; Jo, H.E.; Oh, Y.J.; et al. Lactobacillus sakei WIKIM30 Ameliorates Atopic Dermatitis-Like Skin Lesions by Inducing Regulatory T Cells and Altering Gut Microbiota Structure in Mice. Front. Immunol. 2018, 9, 1905. [CrossRef]

150. Kim, J.-Y.; Park, B.-K.; Park, H.-J.; Park, Y.-H.; Kim, B.-O.; Pyo, S. Atopic dermatitis-mitigating effects of new Lactobacillus strain, Lactobacillus sakei probio 65 isolated from Kimchi. J. Appl. Microbiol. 2013, 115, 517-526. [CrossRef]

151. Jang, S.-E.; Trinh, H.-T.; Chung, Y.-H.; Han, M.J.; Kim, D.-H. Inhibitory effect of Lactobacillus plantarum K-1 on passive cutaneous anaphylaxis reaction and scratching behavior in mice. Arch. Pharmacal Res. 2011, 34, 2117-2123. [CrossRef]

152. Lee, S.Y.; Sekhon, S.S.; Kim, H.C.; Won, K.; Ahn, J.-Y.; Lee, K.; Kim, Y.-H. Anti-inflammatory effect of lactic acid bacteria isolated from kimchi on acid-induced acute colitis in model mice. Toxicol. Environ. Health Sci. 2017, 9, 279-283. [CrossRef]

153. Park, J.S.; Joe, I.; Rhee, P.D.; Jeong, C.S.; Jeong, G. A lactic acid bacterium isolated from kimchi ameliorates intestinal inflammation in DSS-induced colitis. J. Microbiol. 2017, 55, 304-310. [CrossRef] [PubMed]

154. Han, K.; Bose, S.; Wang, J.-H.; Kim, B.-S.; Kim, M.J.; Kim, E.-J.; Kim, H. Contrasting effects of fresh and fermented kimchi consumption on gut microbiota composition and gene expression related to metabolic syndrome in obese Korean women. Mol. Nutr. Food Res. 2015, 59, 1004-1008. [CrossRef] [PubMed]

155. Kim, E.K.; An, S.-Y.; Lee, M.-S.; Kim, T.H.; Lee, H.-K.; Hwang, W.S.; Choe, S.J.; Kim, T.-Y.; Han, S.J.; Kim, H.J. Fermented kimchi reduces body weight and improves metabolic parameters in overweight and obese patients. Nutr. Res. 2011, 31, 436-443. [CrossRef] [PubMed]

156. Al Loman, A.; Ju, L.-K. Soybean carbohydrate as fermentation feedstock for production of biofuels and value-added chemicals. Process Biochem. 2016, 51, 1046-1057. [CrossRef]

157. Riciputi, Y.; Serrazanetti, D.I.; Verardo, V.; Vannini, L.; Caboni, M.F.; Lanciotti, R. Effect of Fermentation on the Content of Bioactive Compounds in Tofu-Type Products; Elsevier: Amsterdam, The Netherlands, 2016; Volume 27, pp. 131-139.

158. Wajid, A.; Ahmad, M.M.; Iftakhar, F.; Qureshi, M.; Ceyhan, A. Nutritive potentials of Soybean and its significance for humans health and animal production: A Review. Eurasian J. Food Sci. Technol. 2020, 4, 41-53.

159. Lee, M.; Park, Y. Chapter 22-Fermented Soypastes, Doenjang and Cheonggukjang, and Obesity. In Nutrition in the Prevention and Treatment of Abdominal Obesity; Watson, R.R., Ed.; Academic Press: San Diego, CA, USA, 2014; pp. $227-237$.

160. Kwon, Y.S.; Lee, S.; Lee, S.H.; Kim, H.J.; Lee, C.H. Comparative Evaluation of Six Traditional Fermented Soybean Products in East Asia: A Metabolomics Approach. Metabolites 2019, 9, 183. [CrossRef]

161. Ross, R.P.; Morgan, S.; Hill, C. Preservation and fermentation: Past, present and future. Int. J. Food Microbiol. 2002, 79, 3-16. [CrossRef]

162. Ahmad, A.; Ramasamy, K.; Majeed, A.B.A.; Mani, V. Enhancement of $\beta$-secretase inhibition and antioxidant activities of tempeh, a fermented soybean cake through enrichment of bioactive aglycones. Pharm. Biol. 2015, 53, 758-766. [CrossRef]

163. Kadar, A.D.; Astawan, M.; Putri, S.P.; Fukusaki, E.J.M. Metabolomics-Based Study of the Effect of Raw Materials to the End Product of Tempe-An Indonesian Fermented Soybean. Metabolites 2020, 10, 367. [CrossRef]

164. Agranoff, J. The Complete Handbook of Tempe: The Unique Fermented Soyfood of Indonesia; American Soybean Association: St. Louis, MO, USA, 1999.

165. Jang, C.H.; Oh, J.; Lim, J.S.; Kim, H.J.; Kim, J.-S. Fermented Soy Products: Beneficial Potential in Neurodegenerative Diseases Foods 2021, 10, 636. [CrossRef] [PubMed]

166. Tjasa Subandi, S.; Kartawidjajaputra, F.; Silo, W.; Yogiara, Y.; Suwanto, A. Tempeh consumption enhanced beneficial bacteria in the human gut. Food Res. 2018, 3, 57-63. [CrossRef]

167. Jensen, G.S.; Lenninger, M.; Ero, M.P.; Benson, K.F. Consumption of nattokinase is associated with reduced blood pressure and von Willebrand factor, a cardiovascular risk marker: Results from a randomized, double-blind, placebo-controlled, multicenter North American clinical trial. Integr. Blood Press. Control 2016, 9, 95. [CrossRef] [PubMed]

168. Pradhananga, M. Effect of processing and soybean cultivar on natto quality using response surface methodology. Food Sci. Nutr. 2019, 7, 173-182. [CrossRef] [PubMed]

169. Fujisawa, T.; Shinohara, K.; Kishimoto, Y.; Terada, A. Effect of miso soup containing Natto on the composition and metabolic activity of the human faecal flora. Microb. Ecol. Health Dis. 2006, 18, 79-84. 
170. Yukihiro, I.; Masayuki, I.; Akemi, M.; Etsuko, K. Intake of Fermented Soybeans, Natto, Is Associated with Reduced Bone Loss in Postmenopausal Women: Japanese Population-Based Osteoporosis (JPOS) Study1. J. Nutr. 2006, 136, 1323.

171. Katsuyama, H.; Ideguchi, S.; Fukunaga, M.; Fukunaga, T.; Saijoh, K.; Sunami, S. Promotion of bone formation by fermented soybean (Natto) intake in premenopausal women. J. Nutr. Sci. Vitaminol. 2004, 50, 114-120. [CrossRef]

172. Li, H.; Feng, F.-Q.; Shen, L.-R.; Xie, Y.; Li, D. Nutritional evaluation of different bacterial douchi. Asia Pac. J. Clin. Nutr. 2007, 16, 215-221. [PubMed]

173. Li, P.; Tang, H.; Shi, C.; Xie, Y.; Zhou, H.; Xia, B.; Zhang, C.; Chen, L.; Jiang, L. Untargeted metabolomics analysis of Mucor racemosus Douchi fermentation process by gas chromatography with time-of-flight mass spectrometry. Food Sci. Nutr. 2019, 7, 1865-1874. [CrossRef] [PubMed]

174. Nout, R. 18-Quality, safety, biofunctionality and fermentation control in soya. In Advances in Fermented Foods and Beverages; Holzapfel, W., Ed.; Woodhead Publishing: Cambridge, UK, 2015; pp. 409-434.

175. Tamang, J.P. Naturally fermented ethnic soybean foods of India. J. Ethn. Foods 2015, 2, 8-17. [CrossRef]

176. Keishing, S.; Banu, T.; Umadevi, M. Effect of fermentation on the nutrient content, antioxidant and antidiabetic activities of Hawaijar, an indigenous fermented soya of Manipur, India. J. Hum. Nutr. Food Sci. 2015, 3, 1066.

177. Jeyaram, K.; Singh, W.M.; Premarani, T.; Devi, A.R.; Chanu, K.S.; Talukdar, N.; Singh, M.R. Molecular identification of dominant microflora associated with 'Hawaijar' - A traditional fermented soybean (Glycine max (L.)) food of Manipur, India. Int. J. Food Microbiol. 2008, 122, 259-268. [CrossRef] [PubMed]

178. Teng, D.; Lin, C. Hsieh, Fermented whole soybeans and soybean paste. In Handbook of food and beverage fermentation technology; Hui, Y.-H., Meunier-Goddik, L., Josephsen, J., Nip, W.-K., S. Stanfield, P., Eds.; Marcel Dekker: New York, NY, USA, 2004; pp. 533-569.

179. Hong, K.-J.; Lee, C.-H.; Kim, S.W. Aspergillus oryzae GB-107 fermentation improves nutritional quality of food soybeans and feed soybean meals. J. Med. Food 2004, 7, 430-435. [CrossRef]

180. Nozue, M.; Shimazu, T.; Charvat, H.; Mori, N.; Mutoh, M.; Sawada, N.; Iwasaki, M.; Yamaji, T.; Inoue, M.; Kokubo, Y.; et al. Fermented soy products intake and risk of cardiovascular disease and total cancer incidence: The Japan Public Health Center-based Prospective study. Eur. J. Clin. Nutr. 2020. [CrossRef] [PubMed]

181. Choi, Y.R.; Shim, J.; Kim, M.J. Genistin: A novel potent anti-adipogenic and anti-lipogenic agent. Molecules 2020, $25,2042$. [CrossRef]

182. Rimbach, G.; De Pascual-Teresa, S.; Ewins, B.; Matsugo, S.; Uchida, Y.; Minihane, A.-M.; Turner, R.; Vafei Adou, K.; Weinberg, P.J.X. Antioxidant and free radical scavenging activity of isoflavone metabolites. Xenobiotica 2003, 33, 913-925. [CrossRef] [PubMed]

183. Wiseman, H.; O’Reilly, J.D.; Adlercreutz, H.; Mallet, A.I.; Bowey, E.A.; Rowland, I.R.; Sanders, T.A. Isoflavone phytoestrogens consumed in soy decrease F2-isoprostane concentrations and increase resistance of low-density lipoprotein to oxidation in humans. Am. J. Clin. Nutr. 2000, 72, 395-400. [CrossRef]

184. Wu, Z.-Y.; Sang, L.-X.; Chang, B. Isoflavones and inflammatory bowel disease. World J. Clin. Case 2020, 8, 2081. [CrossRef]

185. Kim, D.H.; Jung, W.S.; Kim, M.E.; Lee, H.W.; Youn, H.Y.; Seon, J.K.; Lee, H.N.; Lee, J.S. Genistein inhibits pro-inflammatory cytokines in human mast cell activation through the inhibition of the ERK pathway. Int. J. Mol. Med. 2014, 34, 1669-1674. [CrossRef]

186. Takasugi, M.; Shimada, K.; Yamada, K.; Arai, H. Effects of soybean isoflavones on the release of chemical mediators from rat peritoneal exudate cells by allergic reaction in vitro. Food Sci. Technol. Res. 2014, 20, 725-730. [CrossRef]

187. Smith, B.N.; Dilger, R.N. Immunomodulatory potential of dietary soybean-derived isoflavones and saponins in pigs. J. Anim. Sci. 2018, 96, 1288-1304. [CrossRef]

188. Masilamani, M.; Wei, J.; Bhatt, S.; Paul, M.; Yakir, S.; Sampson, H.A. Soybean isoflavones regulate dendritic cell function and suppress allergic sensitization to peanut. J. Allergy Clin. Immunol. 2011, 128, 1242-1250.e1241. [CrossRef]

189. Vo, T.S. Natural products targeting FceRI receptor for anti-allergic therapeutics. J. Food Biochem. 2020, 44, e13335. [CrossRef]

190. Wu, L.C. Immunoglobulin E receptor signaling and asthma. J. Biol. Chem. 2011, 286, 32891-32897. [CrossRef]

191. Bhatt, P.C.; Pathak, S.; Kumar, V.; Panda, B.P. Attenuation of neurobehavioral and neurochemical abnormalities in animal model of cognitive deficits of Alzheimer's disease by fermented soybean nanonutraceutical. Inflammopharmacology 2018, 26, 105-118. [CrossRef]

192. Choi, J.; Kwon, S.-H.; Park, K.-Y.; Yu, B.P.; Kim, N.D.; Jung, J.H.; Chung, H.Y. The Anti-Inflammatory Action of Fermented Soybean Products in Kidney of High-Fat-Fed Rats. J. Med. Food 2011, 14, 232-239. [CrossRef]

193. He, L.-X.; Abdolmaleky, H.M.; Yin, S.; Wang, Y.; Zhou, J.-R. Dietary Fermented Soy Extract and Oligo-Lactic Acid Alleviate Chronic Kidney Disease in Mice via Inhibition of Inflammation and Modulation of Gut Microbiota. Nutrients 2020, $12,2376$. [CrossRef] [PubMed]

194. Takagi, T.; Naito, Y.; Higashimura, Y.; Ushiroda, C.; Mizushima, K.; Ohashi, Y.; Yasukawa, Z.; Ozeki, M.; Tokunaga, M.; Okubo, T.; et al. Partially hydrolysed guar gum ameliorates murine intestinal inflammation in association with modulating luminal microbiota and SCFA. Br. J. Nutr. 2016, 116, 1199-1205. [CrossRef] [PubMed]

195. Vrakas, S.; Mountzouris, K.C.; Michalopoulos, G.; Karamanolis, G.; Papatheodoridis, G.; Tzathas, C.; Gazouli, M. Intestinal bacteria composition and translocation of bacteria in inflammatory bowel disease. PLoS ONE 2017, 12, e0170034. [CrossRef] [PubMed] 
196. Jeong, D.Y.; Daily, J.W.; Lee, G.H.; Ryu, M.S.; Yang, H.-J.; Jeong, S.-Y.; Qiu, J.Y.; Zhang, T.; Park, S. Short-Term Fermented Soybeans with Bacillus amyloliquefaciens Potentiated Insulin Secretion Capacity and Improved Gut Microbiome Diversity and Intestinal Integrity To Alleviate Asian Type 2 Diabetic Symptoms. J. Agric. Food Chem. 2020, 68, 13168-13178. [CrossRef] [PubMed]

197. Huang, H.; Krishnan, H.B.; Pham, Q.; Yu, L.L.; Wang, T.T. Soy and Gut Microbiota: Interaction and Implication for Human Health. J. Agric. Food Chem. 2016, 64, 8695-8709. [CrossRef] [PubMed]

198. Inoguchi, S.; Ohashi, Y.; Narai-Kanayama, A.; Aso, K.; Nakagaki, T.; Fujisawa, T. Effects of non-fermented and fermented soybean milk intake on faecal microbiota and faecal metabolites in humans. Int. J. Food Sci. Nutr. 2012, 63, 402-410. [CrossRef] [PubMed]

199. Cheng, I.C.; Shang, H.F.; Lin, T.F.; Wang, T.H.; Lin, H.S.; Lin, S.H. Effect of fermented soy milk on the intestinal bacterial ecosystem. World J. Gastroenterol. 2005, 11, 1225-1227. [CrossRef] [PubMed]

200. Jeong, D.-Y.; Ryu, M.S.; Yang, H.-J.; Park, S. $\gamma$-PGA-Rich Chungkookjang, Short-Term Fermented Soybeans: Prevents Memory Impairment by Modulating Brain Insulin Sensitivity, Neuro-Inflammation, and the Gut-Microbiome-Brain Axis. Foods 2021, 10, 221. [CrossRef] [PubMed]

201. Katagiri, R.; Sawada, N.; Goto, A.; Yamaji, T.; Iwasaki, M.; Noda, M.; Iso, H.; Tsugane, S. Association of soy and fermented soy product intake with total and cause specific mortality: Prospective cohort study. BMJ 2020, 368, 1-12. [CrossRef] 